\title{
Cadmium-Zinc interactions in a hydroponic system using Ceratophyllum demersum L.: adaptive ecophysiology, biochemistry and molecular toxicology
}

\author{
Parameswaran Aravind and Majeti Narasimba Vara Prasad*
}

Department of Plant Sciences, School of Life Sciences, University of Hyderabad, Hyderabad 500046 Indra. *Corresponding author: mnvsl@uohyd.ernet.in

The interaction between an essential micronutrient, $\mathrm{Zn}$ and a toxic non-essential element, $\mathrm{Cd}$ has been comprehensively reviewed based on our experiments conducted with Ceratophyllum demersum L. in a hydroponic system. Since $\mathrm{Cd}$ and $\mathrm{Zn}$ belong to the group IIB transition elements and show similarities in chemistry, geochemistry and environmental properties, it would be one of the elemental pairs of choice to investigate metal-metal interactions. Evidence in support of the protective role of $\mathrm{Zn}$ against $\mathrm{Cd}$ toxicity in Ceratophyllum demersum L. is presented in this review. Based on our experimental results, we conclude that the antioxidant properties of $\mathrm{Zn}$ play an important role in counteracting $\mathrm{Cd}$ toxicity.

Key words: antagonistic, antioxidant, enzyme conformation, metal interactions, redox pool.

Interações cádmio-zinco em um sistema hidropônico usando Ceratophyllum demersum L.: ecofisiologia adaptativa, bioquímica e toxicologia molecular: A interação entre um micronutriente essencial, Zn, e um elemento tóxico não essencial, $\mathrm{Cd}$, é amplamente revisada com base em nossos experimentos com Ceratophyllum demersum L. em um sistema hidropônico. Desde que $\mathrm{Cd}$ e $\mathrm{Zn}$ pertencem ao mesmo grupo IIB de elementos de transição e mostram semelhanças nas propriedades química, geoquímica e ambiental, poderiam ser os elementos de escolha para investigar as interações metal-metal. Com base em nossos resultados experimentais, apresentamos, nesta revisão, evidências a favor de um papel de proteção antioxidativo de Zn contra a toxidade de $\mathrm{Cd}$ em Ceratophyllum demersum $\mathrm{L}$.

Palavras-chave: antagonista, antioxidante, antagonístico, conformação enzimática, interação metálica, pool redox.

\section{INTRODUCTION}

Heavy metal pollution is of considerable importance and relevant to the present scenario due to the increasing levels of pollution and its obvious impact on human health through the food chain (Hadjiliadis, 1997). Aquatic ecosystems act as the receptacle for various contaminants from natural and anthropogenic sources such as effluents from mines, smelters, industries, excessive use of fertilizers and pesticides, agricultural runoff, and partially from aerial deposition (Ross, 1994; KabataPendias 2001; Adriano 2001). It is known that unfavourable effects of heavy metals on plants are manifested, among others, by inhibiting the normal uptake and utilization of mineral nutrients (Trivedi and Erdei, 1992). Most of the experimental data on $\mathrm{Cd}$ toxicity leaves a dearth of information on the specifics of essential $(\mathrm{Cu}, \mathrm{Fe}, \mathrm{Zn})$ and non-essential metals $(\mathrm{Pb}, \mathrm{Hg})$ (Rauser, 2000) and few studies have been designed specifically to address the effect of micronutrient status on toxicity from exposure to non-essential metals (Peraza et al., 1998). It is notable that metalliferous environments are often contaminated by more than one metal in potentially toxic concentrations (Wallace, 1982; Siedlecka, 1995) that may have synergistic, additive or antagonistic effects on plants (Siedlecka, 1995). Therefore, the effects of metal mixtures on model plant systems need to be investigated critically as the phytotoxicity and interactive aspects of metal mixtures are complex processes (Taylor, 1989; Rauser, 2000). Knowledge about the biochemical and molecular mechanisms by which plants tolerate multiple metal stress can bring a thorough understanding of the plasticity of metabolic pathways and their limits of functioning, which is essential for genetic engineering approaches aimed at improving the cellular defense mechanism (Xiang et al., 2001; Prasad and Strzałka, 2002; Prasad, 2004b). 


\section{Cadmium vs Zinc: Toxicology and occurrence}

It is a common characteristic of all life forms that elements required for metabolism are accumulated and toxic metals excluded in certain plant species (Baker, 1981). Cadmium $\left({ }^{112.41} \mathrm{Cd}_{48}\right)$, a group IIB transition element is a non-essential and toxic element, without any metabolic significance. Cadmium pollution is increasing due to excessive mining, industrial usage and other anthropogenic activities (De, 1992; Prasad, 1995a). In addition, some phosphate fertilizers applied to crops have been found to contain high levels of $\mathrm{Cd}$ ( $\mathrm{He}$ and Singh, 1994). Cadmium released into the environment tends to concentrate in soils and sediments, where it is potentially available to rooted plants. The available $\mathrm{Cd}$ thereby enters biogeochemical cycles, becomes bioconcentrated (Devi et al., 1996) and even affects human health (for example, the Itai-itai disease caused by Cd-contaminated rice in Japan) (Rivai et al., 1990). Cadmium has been classified as a group I human carcinogen by the International Agency for Research on Cancer (IARC, 1993; Goering et al., 1994; Waalkes, 2000). On the other hand $\mathrm{Zinc}\left({ }^{65.39} \mathrm{Zn}_{30}\right)$, another group IIB transition element, is one of the most essential micronutrients for the plant system. Zinc plays a fundamental role in several of the critical cellular functions such as protein metabolism, gene expression, chromatin structure, photosynthetic carbon metabolism and indole acetic acid metabolism (Vallee and Falchuk, 1993; Marschner, 1995; Prasad, 1995; Cakmak and Braun, 2001). Zinc is an important component of many vital enzymes having a catalytic, co-catalytic or structural role, as well as being a structural stabilizer for proteins, membrane and DNA-binding proteins (Zn-fingers) (Vallee and Falchuk, 1993), yet it is toxic at high concentrations. Cadmium and Zinc (IIB transition elements) have a similar electronic configuration and valence state, possessing equal affinities for sulphur, nitrogen and oxygen ligands (Nieboer and Richardson, 1980) and hence similar geochemical and environmental properties (Nan et al., 2002). Cadmium is often associated with $\mathrm{Zn}$ as a contaminant of up to $5 \%$ in the processed $\mathrm{Zn}$ ores of $\mathrm{Zn}$ mines and smelters (Adriano, 2001). Similarly, tyres containing $\mathrm{ZnO}$ and sewage sludge applied to agricultural soils also contain Cd (Sherlock, 1986) as a major contaminant. It has been hypothesized that elements whose physical and chemical properties are similar will act antagonistically to each other biologically (Das et al., 1997). In the recent years, a number of workers have documented responses of plants to combinations of $\mathrm{Zn}$ and $\mathrm{Cd}$ in soil as well as in solution culture (Thys et al., 1991; Smilde et al., 1992; Symeonidis and Karataglis, 1992; Mckenna et al., 1993, Zhou et al., 1994; Chaoui et al.,
1997). This aspect has also been studied in soil-crop systems under field conditions (Nan et al., 2002), but here the study was limited to the bioavailability and bioaccumulation of $\mathrm{Zn}$ and $\mathrm{Cd}$ by the tested plant systems. Nevertheless, investigations focussing on the adaptive physiological and biochemical mechanisms of the interaction between $\mathrm{Zn}$ and $\mathrm{Cd}$ are rather scanty. Moreover, in view of the conflicting results in earlier studies, a clear understanding of potential interaction between $\mathrm{Zn}$ and $\mathrm{Cd}$ has yet to appear. We have initiated investigations on various aspects focussing on the biochemistry of Cd-Zn interactions (Aravind and Prasad, 2003; 2004a,b). Investigations on the same lines have begun with other systems also (Koleli et al., 2004). This review critically analyzes the adaptive ecophysiology, biochemistry, and the molecular toxicological aspects of $\mathrm{Cd}-\mathrm{Zn}$ interactions.

\section{Ceratophyllum demersum L. -an ideal aquatic macrophyte for toxicity bioassays}

Aquatic plants are known to accumulate heavy metals and are being considered for phytoremediation (Prasad et al., 2001). Ceratophyllum demersum L. belongs to the order Nymphaeales and family Ceratophyllaceae (the family of hornworts), grows in shallow, muddy, quiescent water bodies at low light intensities. C. demersum is a convenient plant for laboratory toxicity bioassays (Holder-Czytko, 1994; Kumar and Prasad, 2004a,b) and is also useful as an oxygenator in closed equilibrated biological aquatic systems (Voeste et al., 2003). Hence we have analyzed the interactions of $\mathrm{Zn}$ and $\mathrm{Cd}$ using $C$. demersum as the model plant system of study. C. demersum is known to be a filter of $\mathrm{Cd}$ (Ornes and Sajwan, 1993; Saygideger and Dogan, 2004; Keskinkan et al., 2004), Cu (Devi and Prasad, 1998), Cr (Garg and Chandra, 1990), Pb (Rai et al., 1995; Saygideger and Dogan, 2004) and $\mathrm{Hg}$ (Suckcharoen, 1979). As this plant has recently been recommended for use in remediation of toxic metals (Rai et al., 1995), metabolic studies on C. demersum are worthwhile using sensitive metabolic parameters (with significant stimulatory or inhibitory effects) that may be used as biomarkers for heavy metal stress, and in elucidating the plant response to multiple metal combinations. Moreover, C. demersum has unique features, which make it ideal for laboratory toxicity bioassays. C. demersum is a submerged floating rootless plant and this avoids the complication of soil-system and root-shoot metal partitioning (Best, 1986; Best and Meulemans, 1979). It is convenient for experimental handling, cost-effective in maintenance and multiplies rapidly, an important pre-requisite for choosing any macrophyte as a material for study. The 
forked leaves of the plant and thin cuticle on the plant surface facilitate uptake of metals from water through its large surface. The response of an organism to deficient or excess levels of metal (i.e. bioassays) can be used to estimate metal impact. Such studies when carried out under defined experimental conditions can provide results that can be extrapolated to the natural environment.

\section{$\mathbf{C d}-\mathrm{Zn}$ interaction in $\boldsymbol{C}$. demersum: Ecophysiology}

a) Competitive inhibition of Cd uptake by $\mathrm{Zn}$ : Our studies on $\mathrm{Cd}-\mathrm{Zn}$ interaction clearly identified the potential toxicity of $\mathrm{Cd}$ and the role of $\mathrm{Zn}$ in antagonizing $\mathrm{Cd}$ toxicity. The distinct toxicity symptoms of chlorosis and necrosis observed under the toxic treatments of $\mathrm{Cd}$ were clearly alleviated by $\mathrm{Zn}$ (figure 1). The inhibitory effect of $\mathrm{Zn}$ on $\mathrm{Cd}$ was reflected directly by analysis of metal accumulation by $C$. demersum. $\mathrm{Zn}$ supplements $(10,50,100$ and $200 \mu \mathrm{M})$ to Cd-treated plants reduced $(26 \%)$ the accumulation of cadmium especially at the $200 \mu \mathrm{M}$ concentration (figure 2). Simultaneously the reduced ( $50 \%$ ) amount of $\mathrm{Zn}$ found in $\mathrm{Cd}-10 \mu \mathrm{M}$ alone treatments was restored to control levels and accumulation increased (79 \%) when Cd-treated plants were supplemented with $\mathrm{Zn}(200 \mu \mathrm{M})$. This suppression in Cd uptake due to the increase in $\mathrm{Zn}$ accumulation indicates a strong competition between $\mathrm{Zn}$ and $\mathrm{Cd}$. Since $\mathrm{Cd}$ and $\mathrm{Zn}$, both taken up as divalent cations, have a similar chemistry (Nieboer and Richardson, 1980), Cd can readily inhibit most of the Zn-dependent processes. Consequently, increased $\mathrm{Zn}$ concentration is able to replace a non-physiological metal like $\mathrm{Cd}$, which may bind to the crucial and functional membrane and enzyme active sites and inactivate their functions (Van Assche and Clijsters, 1990; Shaw et al., 2004). Cadmium has been described as an antimetabolite of $\mathrm{Zn}$ due to the observed Zn deficiency in most of the Cd-treated systems (Peraza et al., 1998), an observation true to our system also. Other reported evidence such as in Glycine max (Cataldo et al., 1983), Holcus lanatus (Symeonidis and Karataglis, 1992) and Lactuca sativa (Thys et al., 1991) also point to depressed $\mathrm{Cd}$ uptake in the presence of $\mathrm{Zn}$.

\section{b) Zn regulates membrane transporter-mediated Cd uptake:}

There are specific metal ion uptake systems in cells especially for essential nutrients that are tightly controlled at both transcriptional and post-transcriptional levels with specific regulatory mechanisms (Lasat et al., 2000). Transport of non-essential elements like $\mathrm{Cd}$ is most likely to occur via transporters of essential cations (Fox and Guerinot, 1998; Souza-Santos et al., 2001). The $\mathrm{Zn}(\mathrm{II})$ transporting activity of ZIP proteins is inhibited by $\mathrm{Cd}(\mathrm{II}), \mathrm{Co}(\mathrm{II})$ and $\mathrm{Cu}(\mathrm{II})$, indicating that $\mathrm{ZIP}$ proteins may transport potentially toxic metals as well as nutrients (Kochian, 1993; Grotz et al., 1998). Apart from ZIP family of transporters, the iron transporters (IRT1) are required for normal iron utilization (Eide, 1997). Cd has also been shown to inhibit iron uptake by IRT transporters, indicating the control of entry through nutrient transporters (Bereczky et al., 2003). In Thlaspi caerulescens, ZNT1 encodes a high affinity transporter, also mediating low affinity Cd transport (Lasat et al., 2000). Many essential physiological processes in plants including the uptake of minerals are dependent on the $\mathrm{H}^{+}$gradient generated by $\mathrm{H}^{+}$ATPase located in the plasma membrane (Michelet and Boutry, 1995, Morsomme and Boutry, 2000). These ATPases belong to the CPx type transporters, which have conserved intramembranous Cys-Pro-Cys or Cys-ProHis motifs (Solioz and Vulpe, 1996; Portillo, 2000). There are reports on regulation (up/down) of $\mathrm{H}^{+}$ATPase by various metals in different systems such as $\mathrm{Cd}$ in Glycine max (Cataldo et al., 1983), Helianthus annus and Triticum aestivum (Fodor
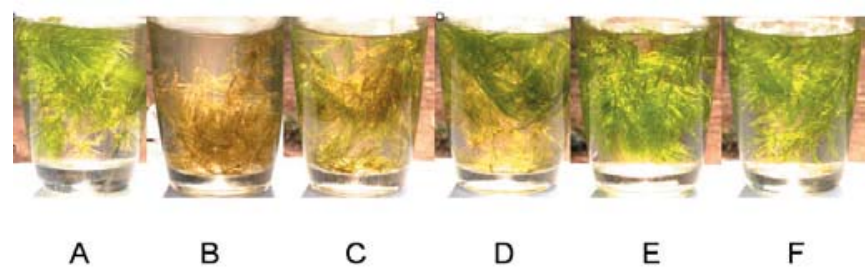

Figure 1. Toxicity bioassay under different metal treatments using C. demersum. A) Control plants without any treatments; B) Cd-10 $\mu \mathrm{M}$; C) Cd-10 $\mu \mathrm{M}+\mathrm{Zn}-10 \mu \mathrm{M}$; D) Cd-10 $\mu \mathrm{M}+\mathrm{Zn}-50 \mu \mathrm{M}$; E) Cd$10 \mu \mathrm{M}+\mathrm{Zn}-100 \mu \mathrm{M}$; F) Cd-10 $\mu \mathrm{M}+\mathrm{Zn}-200 \mu \mathrm{M}$ treatments.

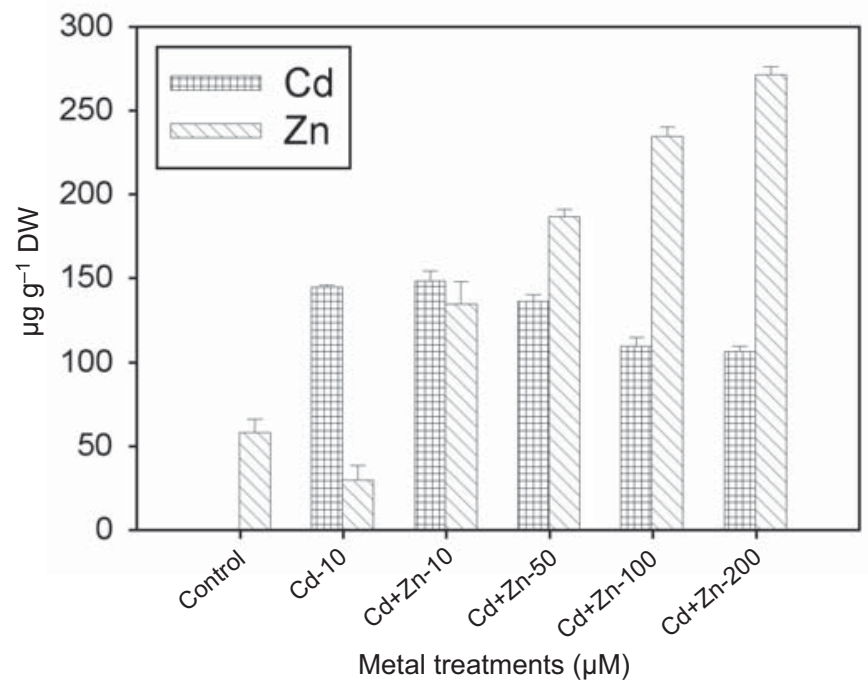

Figure 2. Metal accumulation in Ceratophyllum demersum treated with $\mathrm{Cd}-10 \mu \mathrm{M}$ and $\mathrm{Zn}(10,50,100$, and $200 \mu \mathrm{M})$. Error bars represent standard errors and an 'asterisk' for $\mathrm{Cd}$ content indicates significant difference from Cd-treated plants; an 'asterisk' for $\mathrm{Zn}$ content indicates significant difference from control plants. 
et al., 1995), Lactuca sativa (Costa and Morel, 1994), and Fe in Zea mays (Souza-Santos et al., 2001). The uptake of Cd by the plant system decreased $(15 \%)$ in the presence of the metabolic inhibitor 2,4-dinitrophenol (DNP) indicating the proton gradient-mediated uptake as one of the routes of active transport into the plant cell (figure 3). According to the chemiosmotic hypothesis, DNP increases proton permeability of biomembranes and thereby breakdown of proton gradients that could explain the pronounced inhibition of Cd uptake (Poole, 1978). Furthermore, the association with $\mathrm{H}^{+}$ATPase is reinforced by the observation of a decrease ( $23 \%$ ) in Cd uptake in the presence of N-N'-dicyclohexylcarbodimide (DCCD), a proteolipid-binding $\mathrm{H}^{+}$ATPase specific inhibitor. This was further justified from the assay of $\mathrm{H}^{+}$ATPase which indicated an increase (27\%) in activity in Cd treatments in the absence of metabolic inhibitors corresponding to the higher uptake of $\mathrm{Cd}$ (figure 4). These results are in agreement with the earlier work on $\mathrm{Cd}$ uptake in C. demersum (Tripathi et al., 1995) and Lactuca sati$v a$ (Costa and Morel, 1994). It should be noted that in Cd treatments with added DNP and DCCD the accumulation of Cd decreased with a simultaneous decrease in $\mathrm{H}^{+}$ATPase activity. $\mathrm{Zn}$ supplementation (10-200 $\mu \mathrm{M})$ along with DNP and DCCD further reduced Cd uptake (33\% and $38 \%$ reduction respective1y). There was absolutely no effect on $\mathrm{Zn}$ uptake by DNP or DCCD. The $\mathrm{H}^{+}$ATPase activity as well as Cd uptake was further reduced by $\mathrm{Zn}$ supplements along with DNP and DCCD indicating direct evidence for the regulation of the $\mathrm{H}^{+}$ATPasemediated proton pumping mechanism by $\mathrm{Zn}$, through which $\mathrm{Zn}$ can indirectly antagonize $\mathrm{Cd}$ entry into the plant cell.

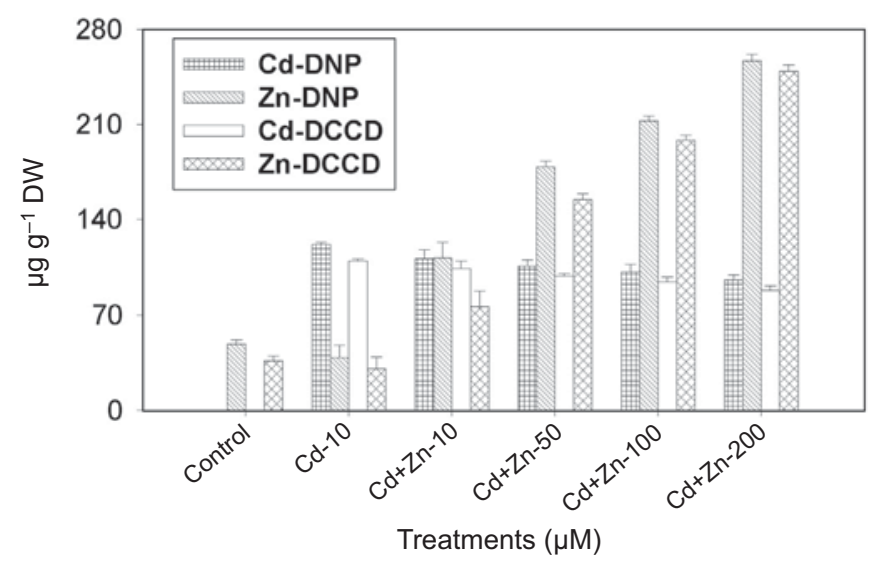

Figure 3. Metal accumulation in $C$. demersum treated with $\mathrm{Cd}-10 \mu \mathrm{M}$ and $\mathrm{Zn}(10,50,100$ and $200 \mu \mathrm{M})$ concentrations in the presence of metabolic inhibitors 2,4-dinitrophenol (DNP) $(10 \mu \mathrm{M})$ and NN' dicyclohexylcarbodimide (DCCD) $(100 \mu \mathrm{M})$. Error bars represent standard errors and an 'asterisk' for $\mathrm{Cd}$ content indicates significant difference from Cd treated plants; an 'asterisk' for $\mathrm{Zn}$ content indicates significant difference from control plants.

\section{Zn-Cd interaction in $C$. demersum: biochemistry}

a) Zn alleviates $\mathrm{Cd}$-induced oxidative stress: Accumulation of $\mathrm{Cd}$ is known to cause oxidative stress through free radicals [superoxide $\left(\mathrm{O}_{2}{ }^{-}\right)$, hydroxyl $(\mathrm{OH} \cdot)$ and hydrogen peroxide $\left(\mathrm{H}_{2} \mathrm{O}_{2}\right)$ ], (Shaw et al., 2004). A variety of macromolecules including proteins, lipids, polysaccharides and nucleic acids are oxidatively modified, and the manifestations of this damage are multifarious (Davies, 2003). In C. demersum $\mathrm{Cd}$ induced strong oxidative stress as evidenced by high levels of lipid peroxidation, electrical conductivity, increased $\mathrm{Na}^{2+}, \mathrm{Ca}^{2+}$, and $\mathrm{K}^{+}$leakage and lipoxygenase activity (table 1) indicating higher lipolytic activity and oxidation of membrane-bound fatty acids causing propagation of lipid peroxidation and hence ion leakage. Cadmium is known to bind to sulphydryl groups of membrane-bound proteins and destabilize the membrane system, by inducing the formation of disulphide links leading to distortion in structure and function of membrane ion channels and hence regulation of uptake/efflux of essential nutrients (Prasad, 1995a). Hence it leads to distortion in membrane structure increasing the electrolyte leakage and loss of ions. Reports in various animal and plant systems related to studies on Zn-deficiency have highlighted the increase in peroxidative damage and oxidative stress, which was completely inhibited under Zn-sufficient conditions (Cakmak and Marschner, 1998a,b; Cakmak, 2000). This indicates that Zn might play an important role in modulating production of ROS and in maintaining cellular homeostasis (Powell, 2000). $\mathrm{Zn}$ supplementation reduced Cd-induced oxidative stress in C. demersum as observed by the decrease in these parameters

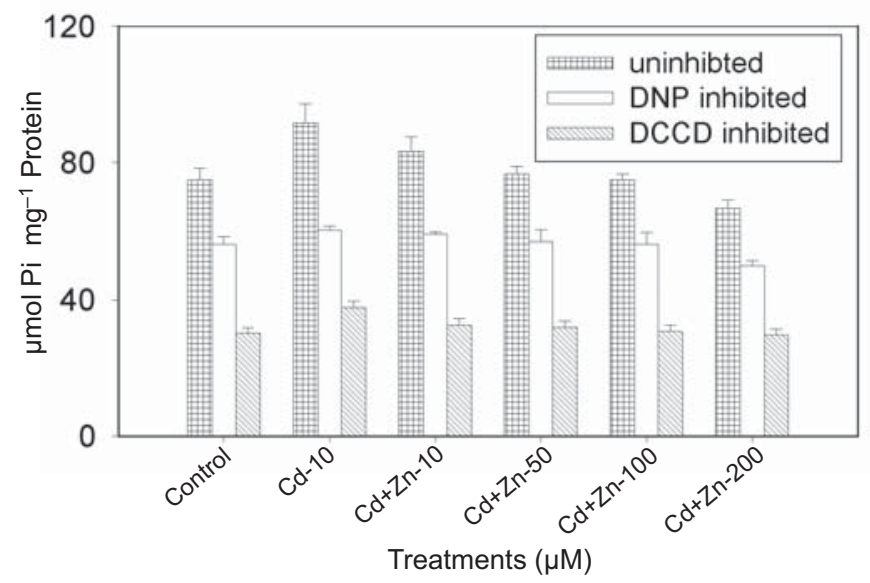

Figure 4. $\mathrm{H}^{+}$ATPase activity in $C$. demersum treated with $\mathrm{Cd}-10$ $\mu \mathrm{M}$ and $\mathrm{Zn}(10,50,100$ and $200 \mu \mathrm{M})$ in the absence of and in the presence of metabolic inhibitors 2,4-dinitrophenol (DNP) (10 $\mu \mathrm{M})$ and N-N' dicyclohexylcarbodimide (DCCD) $(100 \mu \mathrm{M})$. Error bars represent standard errors and an 'asterisk' indicates significant difference from $\mathrm{Cd}$ treated plants. 


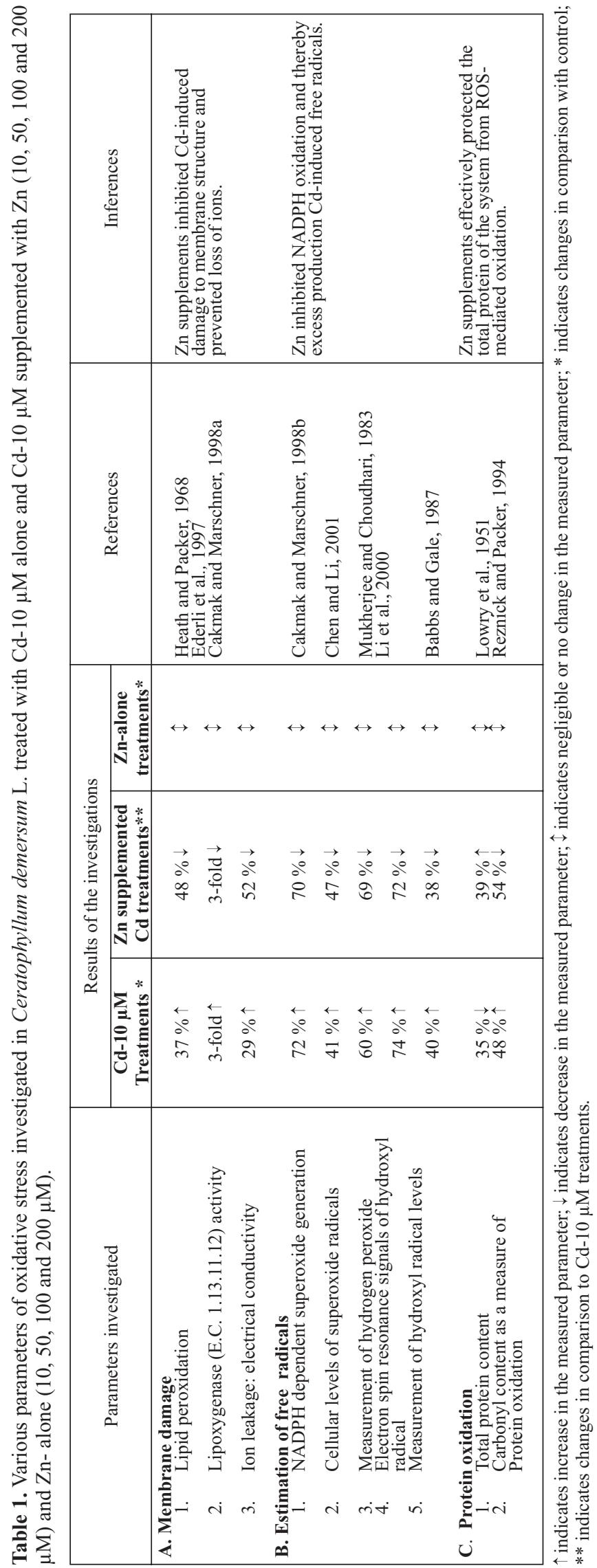

indicating the intact membrane structural integrity. The chemical properties of $\mathrm{Zn}$ are favourable to various metabolic reactions, since under physiological conditions $\mathrm{Zn}$ has the unique property of existing in a univalent state without undergoing redox cycling (Vallee and Auld, 1990). Elemental Zn has two outer shell electrons, which are readily lost in water at $\mathrm{pH} 7.4$ to form $\mathrm{Zn}^{2+}$. Zinc carries out its biochemical functions as a divalent cation primarily when bound to enzymes and other proteins (Vallee and Falchuk, 1993). Further reduction to $\mathrm{Zn}^{+1}$ or $\mathrm{Zn}^{0}$ does not occur as there is no biological reductant strong enough (i.e. having a high enough redox potential) to reduce $\mathrm{Zn}$. Similarly $\mathrm{Zn}$ cannot be oxidized further to $\mathrm{Zn}^{3+}$ since it possesses a full complement of ' $3 d$ ' electrons and removing one of these would require more energy than any known biological oxidant could mobilize (Vallee and Falchuk, 1993). Furthermore, due to filled $d$-shell orbitals, $\mathrm{Zn}^{2+}$ has a ligand-field stabilization energy of zero (McCall et al., 2000). Zinc has a very low electrochemical potential, higher charge density, and hence very high ionization energy would be required to remove or add electrons beyond the $\mathrm{Zn}^{2+}$ state (Schǘtzendǘbel and Polle, 2002). Hence $\mathrm{Zn}$ is stable in biological medium where the oxidoreductive potential is subjected to continuous flux (Vallee and Falchuk, 1993; Cakmak, 2000; Powell, 2000; Zago and Oteiza, 2001). This property forms the basis for the efficient functioning of $\mathrm{Zn}$ in biological systems. Zn-alone-treated plants however did not show any variation in the above parameters (table 1). Zinc prefers binding to the - $\mathrm{SH}$ groups of the membrane protein moiety and protects the phospholipids and proteins from thiol oxidation and disulphide formation (Chvapil, 1973) either by direct binding or to a site close to the sulphydryl group or through a conformational change. This results in an apparent stability of the enzymes, membrane proteins as well as the lipid structure (Bray and Bettger, 1990; Powell, 2000) and hence affords protection from $\mathrm{Cd}$-induced sulphydryl oxidation and structural damage.

b) Influence of $\mathrm{Cd}$-Zn interaction on the free radical species and antioxidants: Divalent cations such as $\mathrm{Cd}$ are known to trigger the oxidation of NADPH leading to superoxide radical production $\left(\mathrm{O}_{2}{ }^{-}\right)$(Kawano et al., 2001) furthering the reaction to hydrogen peroxide $\left(\mathrm{H}_{2} \mathrm{O}_{2}\right)$, and hydroxyl radical $(\mathrm{OH} \cdot)$ formation (Fleschin et al., 2000). Cadmium enhanced free radical production in $C$. demersum by mediating enhanced NADPH oxidation (table 1). The protective effect of $\mathrm{Zn}$ has been shown to be due to its ability to inhibit NADPH oxidation and oxygen-centered free radical generation as analyzed under Zn deficient conditions where the NADPH- 
dependent $\mathrm{O}_{2}$ - radical production increased (Cakmak and Marschner, 1988b,c). This is in complete agreement with our results where $\mathrm{Zn}$ supplementation effectively inhibited NADPH oxidation and hence $\mathrm{O}_{2} \cdot{ }^{-}$radical formation, thereby preventing ROS formation and maintenance of the NADPH redox pool. $\mathrm{Cd}$ increased $\mathrm{OH}$ radical levels as revealed by the very high increase in signal amplitude in electron spin resonance spectra of $\mathrm{OH} \cdot$ signals (table 1) using 5,5-dimethyl pyrroline-N-oxide as a spin trap. Our observations also indicated a decrease in the total protein content and enhanced oxidation of proteins measured as carbonyls under Cd toxicity (table 1). Our results clearly exhibit the true antioxidative and ROS scavenging capacity enhanced by $\mathrm{Zn}$ supplementation as there was complete inhibition of formation of ROS in the plant system, an observation that would definitely justify $\mathrm{Zn}$ as an element with potential antioxidant properties. $\mathrm{Zn}$ supplements were effective in not only inhibiting free radical formation but also restored and slightly enhanced the total protein content by inhibiting the oxidation of proteins measured as carbonyls (table 1). This is in agreement with several studies in a number of plant species (Cakmak et al., 1989; Hossain et al., 1997), indicating that $\mathrm{Zn}$ is indeed one of the key elements regulating protein synthesis. Moreover the reduction of protein carbonyl formation indicated protection of cellular protein from ROSmediated oxidative damage.

Variations in the responses of antioxidant enzymes to $\mathrm{Cd}$ toxicity are well known (Van Ascche and Clijsters, 1990). The enhanced SOD activity of both Cu/Zn SOD and MnSOD observed in $\mathrm{Zn}$-supplemented Cd-treated plants (table 2) indicate enhanced $\mathrm{O}_{2} \cdot{ }^{--}$scavenging and dismutation to $\mathrm{H}_{2} \mathrm{O}_{2}$. This metalloenzyme possesses $\mathrm{Zn}$ as one of its active site metals for its co-catalytic functioning (Vallee and Falchuk, 1993) along with $\mathrm{Cu}$ in $\mathrm{Cu} / \mathrm{Zn}$ SOD. The enzyme has been shown to decrease in activity under Zn-deficient conditions (Cakmak and Marschner, 1993; Cakmak et al., 1997) but not under $\mathrm{Cu}$ deficiency, indicating a direct role of $\mathrm{Zn}$ in regulating SOD activity. $\mathrm{Zn}$ is known to stabilize superoxide dismutase and hence a higher $\mathrm{Zn}$ supplement is able to enhance dismutation of the Cd-increased $\mathrm{O}_{2} \cdot$ radical, facilitating its detoxification in the subsequent steps utilizing CAT and APX. These observations indicate the probable role of $\mathrm{Zn}$ in stimulating the biosynthesis of antioxidant enzymes (Cakmak, 2000 ) as evidenced by a variety of biological systems that have shown a relationship between the relative tolerance to oxidative stress and the capacity of an organism to enhance intracellular antioxidant enzyme activity by induction of $d e$ novo protein synthesis (Miszalski et al., 1998). It is likely

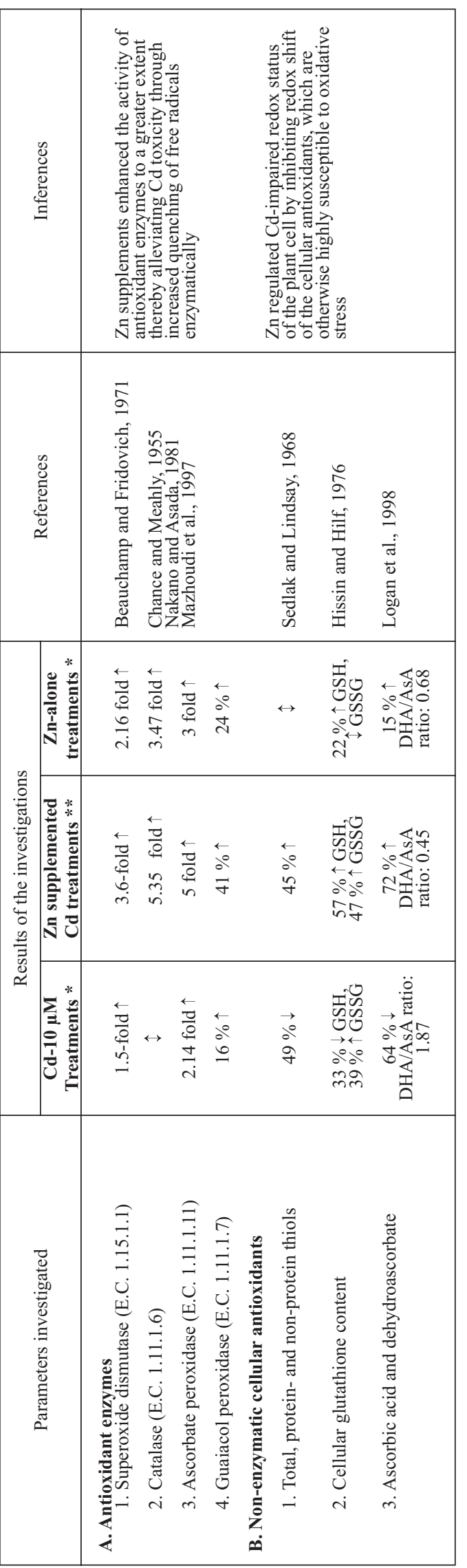


that excess production of ROS by Cd would have inactivated SOD and CAT as very high levels of $\mathrm{H}_{2} \mathrm{O}_{2}$ inhibit $\mathrm{Cu} / \mathrm{Zn}$ SOD (Casano et al., 1997; Cakmak, 2000) through $\mathrm{Cu}^{2+}$ to $\mathrm{Cu}^{+}$reduction and formation of excess hydroxyl radicals or inactivation of the enzyme-bound heme group (Luna et al., 1994) in CAT by $\mathrm{O}_{2}{ }^{-}$leading to impaired CAT activity. Zn stimulated CAT, POD and APX activity (table 2) effectively scavenging $\mathrm{Cd}$-increased $\mathrm{H}_{2} \mathrm{O}_{2}$ levels in the plant system (Anabel et al., 2002). The Zn-enhanced ROS scavenging antioxidant enzyme activity directly indicates the efficiency of $\mathrm{Zn}$ as an antioxidant thereby acting against $\mathrm{Cd}$-induced oxidative stress.

c) Zn-enhanced functioning of the ascorbate-glutathione cycle and glutathione metabolism enzymes - Antioxidant pathways involved in Cd detoxification: The endogenous non-enzymatic antioxidants include carotenoids, $\alpha$-tocopherol, flavonoids, phenolic acids, amino acids, polyamines, ascorbate (AsA) (Pallanca and Smirnoff, 2000), thiols (-SH) and glutathione (GSH) (Foyer et al., 2001), which are effectively free-radical scavengers (Alscher et al., 1997). Cadmium-induced oxidation of - $\mathrm{SH}$ groups is one of the earliest events observable in a living system. Cadmium induced a severe decrease in the redox pool of the plant cell - thiols, glutathione (GSH) as well as total ascorbate levels, and simultaneously oxidized ascorbate (AsA) to dehydroascorbate (DHA) and glutathione (GSH) to its oxidized form (GSSG) (table 2), a true indication of oxidative stress. GSH functions as a stress indicator shifting the redox state in response to oxidative stress (Noctor et al., 1998; Devi and Prasad, 1998). The formation of oxidized GSSG in Cd-10 $\mu \mathrm{M}$ treatments could be due to the reaction of GSH with oxyradicals generated by the toxic concentration of $\mathrm{Cd}$ as in any other metal stress resulting in elevated GSSG (Nagalakshmi and Prasad, 2001). The Cd-decreased GSH pool and altered GSH/GSSG ratio would apparently render the cell more sensitive to other forms of stress such as photooxidation, ozone etc (Xiang et al., 2001). Zinc clearly restored the lost thiol pools, a natural phenomenon associated with Zn (Cakmak 2000). It also restored and enhanced GSH to a great extent, with a simultaneous decrease in the oxidized GSSG. Zn probably modulates GSH levels by regulating its biosynthesis or by protecting the reactive cysteine residue of GSH (Cakmak, 2000) or through the efficient functioning of GR (Foyer and Halliwell, 1976). Zn-protected AsA would react efficiently with $\mathrm{O}_{2}{ }^{--}$, singlet oxygen (directly), ozone (chemically), and $\mathrm{H}_{2} \mathrm{O}_{2}$ (enzymatically through APX), and thereby assist in neutralizing these potential toxicants
(Smirnoff et al., 2001). Cd-induced changes in the levels of cellular antioxidants drastically affected and impaired the functioning of the ascorbate-glutathione cycle (Zhang and Kirkham, 1996). The ascorbate-glutathione cycle (AGC) is a major $\mathrm{H}_{2} \mathrm{O}_{2}$ scavenging antioxidant pathway that operates both in chloroplasts as well as the cytosol (Zhang and Kirkham, 1996), where cycling of the redox molecules (AsA, GSH) takes place with effective utilization of the AGC enzymes [ascorbate peroxidase-APX, monodehydroascorbate reductaseMDHAR, dehydroascorbate reductase- DHAR and glutathione reductase- GR]. Zn supplementation effectively recovered the AGC pathway (table 3) simultaneously enhancing the activity of all the involved enzymes and thereby maintaining the GSH and AsA levels (table 2). The toxicity induced by $\mathrm{Cd}$ inhibited the activity of MDHAR, as well as DHAR there by increasing dehydroascorbate (DHA) formation. Extremely high DHA accumulation is generally considered as a negative event for cell metabolism (De Gara et al., 2000). Therefore a higher MDHAR activity and hence DHAR, was adopted as the strategy for inhibiting MDHA disproportionation and DHA reduction (Drażkiewicz et al., 2003) by $\mathrm{Zn}$ to counteract $\mathrm{Cd}$ induced disturbances of the AsA redox status in C. demersum. $\mathrm{Zn}$ induced a very high increase in the activity of Glutathione reductase (GR) in $C$. demersum (table 3 ), which could have resulted from de novo GR protein synthesis connected to the trigger mechanism initiated by $\mathrm{Cd}$-induced oxidative stress (Drażkiewicz et al., 2003). GR is extremely sensitive to inhibition by heavy metal ions like $\mathrm{Cd}^{2+}, \mathrm{Cu}^{2+}, \mathrm{Fe}^{3+}$, and by compounds that react with the-SH groups due to the presence of thiol groups at the active site of the enzyme (Smith et al., 1989). Active participation in thiol protection (Cakmak, 2000; Powell, 2000) is a function particularly associated with $\mathrm{Zn}$, and leads to enhanced activity of GR ensuring efficient cycling and utilization of the pyridine nucleotide reducing power .

Glutathione metabolism involves many reactions where glutathione is synthesized, degraded, conjugated or oxidized (Noctor et al., 1998). Our own experimental evidence showed that $\mathrm{Cd}$ as well as $\mathrm{Zn}$ did not have a great affect on $\gamma$-glutamylcysteine synthetase ( $\gamma$-GCS), an enzyme of GSH synthesis (table 3). Glutathione-S-transferases (GST) catalyze both GSH-dependent conjugation and reduction thereby playing an active role in detoxification since GST mRNA responds very quickly to oxidative stress (Conklin and Lasat, 1995). The observed limited role of GST in Cdtreated plants may be due to its inhibition by peroxidation of GST protein or inactivation of GST genes. On the other hand Zn supplementation to $\mathrm{Cd}-10 \mu \mathrm{M}$ treatments activated GST 


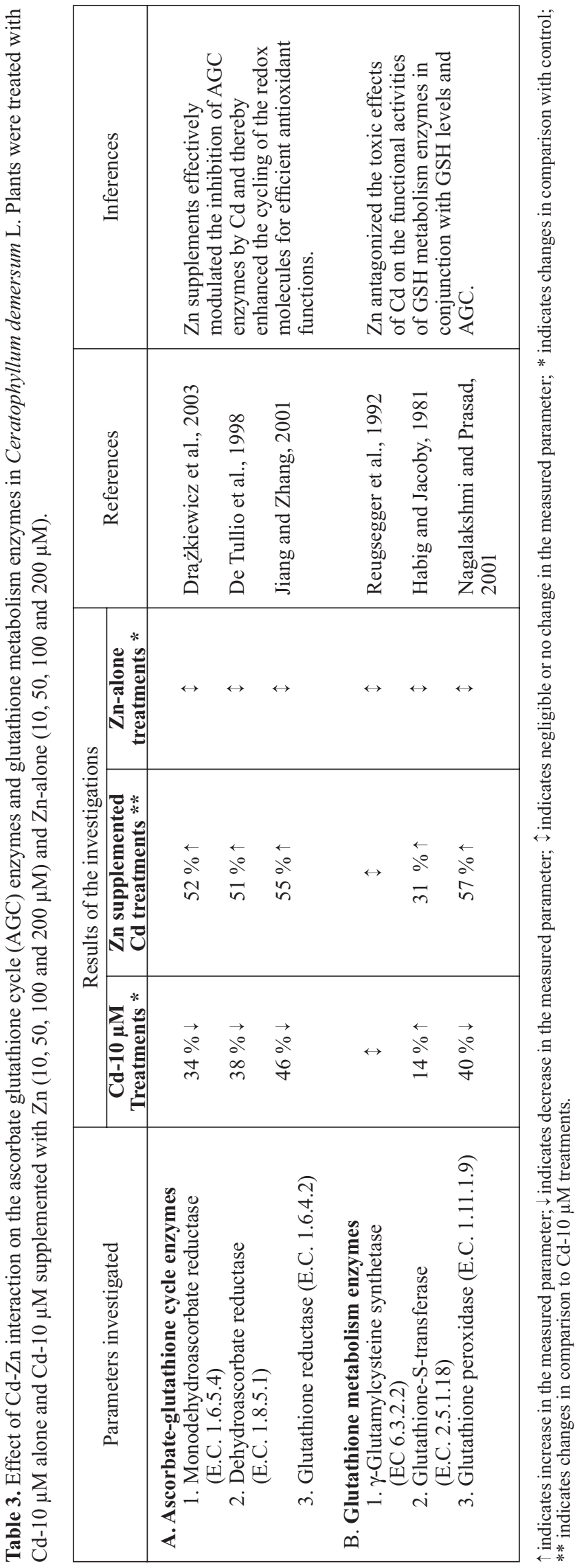

to a great extent (table 3) indicating increased detoxification. $\mathrm{Zn}$, by triggering GSTs, detoxifies endogenously-produced electrophiles like 4-hydroxy alkenals and base propenals (Marrs, 1996). The enzyme GST conjugates itself to these products formed by oxidative degradation of lipids and nucleic acids and prevents them from propagating further damage (Nagalakshmi and Prasad, 2001; Foyer et al., 2001). Glutathione peroxidase (GSH-PX) is a part of the arsenal of protective enzymes, and is involved in coupling reactions with glutathione and cellular detoxification of $\mathrm{H}_{2} \mathrm{O}_{2}$, as a response to oxidative stress (Drotar et al., 1985). Zn played a key role in enhancing Cd-inhibited GSH-PX activity and hence its $\mathrm{H}_{2} \mathrm{O}_{2}$ scavenging activity.

Plants treated with Zn only did not show significant changes in the above parameters indicating that the chosen range of $\mathrm{Zn}$ concentrations did not affect the physiology of the plants in any way. In conclusion, the higher reduction state of the ascorbate and glutathione pool, consistent with higher activities of APX, MDHAR, DHAR and GR, as well as GST and GSHPX enzymes in Zn-supplemented Cd-treated plants, indicate that the specific role of $\mathrm{Zn}$ in promoting ROS detoxification through AGC enzymes also involves GSH-metabolism.

d) Carbonic anhydrase - $A$ model enzyme with relevance to $C d$ $Z n$ interaction: Carbonic anhydrase (CA) has been extensively studied in many organisms from cyanobacteria to higher plants, animals and human systems (Armstrong et al., 1966; Atkins et al., 1972; Smith and Ferry, 2000; Tripp et al., 2001). CA has been presumed to have an active function in photosynthetic organisms (Sultmeyer et al., 1993) and has been the topic of interest in many aquatic systems where the availability of $\mathrm{CO}_{2}$ is low (the predominant form of dissolved inorganic carbon being $\mathrm{HCO}_{3}^{-}$) and further complicated by its slower diffusion rates in water, being $1 \times 10^{4}$ times slower than in air (Badger, 1987). In order to maintain photosynthetic efficiency under low $\mathrm{CO}_{2}$ availability, a carbon-concentrating mechanism (CCM) functions (Lane and Morel, 2000). This CCM has two components, namely a mechanism for taking up $\mathrm{HCO}_{3}{ }^{-}$and a $\mathrm{Zn}$-requiring $\mathrm{CA}$ that catalyses the interconversion of $\mathrm{HCO}_{3}^{-}$ to $\mathrm{CO}_{2}$ (Badger and Price, 1994). Our investigations with $C$. demersum revealed the existence of an active $\mathrm{Zn}$-dependent $\mathrm{CA}$ in $\mathrm{C}$. demersum as in other aquatic angiosperms (viz. Myriophyllum, Hydrilla, Elodea) where $\mathrm{HCO}_{3}^{-}$diffusion and then conversion to $\mathrm{CO}_{2}$ by CA plays a vital role in maintaining the inorganic carbon levels (Elzenga and Prins, 1988). The toxicity of Cd-10 $\mu \mathrm{M}$ drastically affected the functioning and activity of CA. However, when Cd-treated plants were 
supplemented with Zn, not only was the CA activity (table 4) restored but activity increased with higher concentrations of $\mathrm{Zn}$. This demonstrates the complete dependence of the active form of this enzyme to the presence of sufficient levels of $\mathrm{Zn}$. It has been suggested that CA activity is a suitable indicator of the levels of physiologically active $\mathrm{Zn}$ in plant tissues (Gibson and Leece, 1981). Cadmium possesses properties identical to Zn (Nieboer and Richarson, 1980). Hence Cd can readily inhibit most of the $\mathrm{Zn}$-dependent processes either by competing for similar sites or displacement/ substitution reactions in occupying the active sites of the $\mathrm{Zn}$ metalloproteins (Nieboer and Richardson, 1980; Siedlecka, 1995). CA purified from $C$. demersum subjected to different treatments can directly corroborate the above statement. There was a distinct loss of recovery as well as catalytic activity in Cd-treated plants, where the novel and important observation that $\mathrm{Cd}$ substituted $\mathrm{Zn}$ in the active site of $\mathrm{CA}$ was also observed (table 4). This was subsequent to a reduction in the $\mathrm{Zn}$ content of the purified enzyme. Thus the theory of $\mathrm{Cd}$ occupying the active sites of important Zn-metalloproteins has been proved by our findings. Carbonic anhydrase molecules devoid of their usual $\mathrm{Zn}$ content would be non-functional and Cd-induced $\mathrm{Zn}$ deficiency per se would lead to impaired protein synthesis (Marschner and Romheld, 1991). Hence the associated photosynthetic processes would also be affected extensively. In many cases it has been reported that removal of $\mathrm{Zn}$ from CA leads to irreversible loss of catalytic activity (Guliev et al., 1992), which corroborates our findings. Cd is known to affect enzymes and proteins through its interaction with - $\mathrm{SH}$ groups as well as inducing redox cycling (Powell, 2000). Moreover the S-P orbital energy separation for $\mathrm{Cd}$ is less than that of $\mathrm{Zn}$, suggesting that excitation of the valence state may be easier for $\mathrm{Cd}$ than for $\mathrm{Zn}$ due to its low charge density (Schǘtzendǘbel and Polle, 2002). Therefore, a higher state of redox cycling by $\mathrm{Cd}$ and destruction of the $\mathrm{Zn}$-thiolate bonds of the enzyme due to oxidation of disulphide groups by an inactive and toxic metal like $\mathrm{Cd}$ would completely impair CA functioning. The CA purified from Cd-treated plants with supplemented $\mathrm{Zn}$ showed a higher recovery as well as a highly active $\mathrm{CA}$ with the $\mathrm{Zn}$ content estimated to be slightly higher than that of the control (table 4). The increased uptake of $\mathrm{Zn}$ would explain the enhanced CA biosynthesis and catalytic activity. Zinc-alone treatments also produced an active purified enzyme with a $\mathrm{Zn}$ content closely comparable to that of the control. The presence of sufficient levels of $\mathrm{Zn}$ in Cd-treated plants with supplemented $\mathrm{Zn}$ strengthens the $\mathrm{Zn}$-metalloprotein interaction through protection of the $-\mathrm{SH}$ groups from thiol oxidation and intramolecular disulphide formation, a function primarily associated with $\mathrm{Zn}$ (Cakmak, 2000; Cakmak and Braun, 2001).

The cadmium-substituted CA enzyme revealed a distorted $\alpha$-helical conformation with unfolding of the $\alpha$-helix to an open coiled structure, as indicated by near UV circular dichroism analysis (table 4). Since CA purified from Cd-10 $\mu \mathrm{M}$ treatments showed metal substitution reactions with $\mathrm{Zn}$, the natural active site co-factor of $\mathrm{CA}$, the electrostatic interactions within the protein molecule would be drastically affected when $\mathrm{Zn}$ is replaced by Cd (Creighton, 1993). This would also induce destabilizing intramolecular repulsive interactions between like charges which would act as the driving force for the unfolding of the macromolecule (Anfinsen, 1973) ultimately distorting the ordered secondary structure. Cadmium substitution had profound effects on the specific tertiary interactions of the aromatic amino acid residues inferred from the spectra of far UV-circular dichroism and UV spectra. Cadmium substitution reduced and shifted the emission maxima of the native fluorescence of tyrosine and tryptophan and increased 8-anilino-1-naphthalene sulfonic acid (ANS)-protein binding. It may be concluded from this observation that the exposure of aromatic amino acid residues from the interior of the hydrophobic pockets of the unfolded enzyme to the external solvent lead to the changes in fluorescence intensity with a concomitant shift in the emission maxima. Thus the exposed hydrophobic pockets of the enzyme react with external 8-ANS dye thereby increasing the fluorescence indicative of protein unfolding. A potent mode of direct attack on protein derives from site-specific metal-catalyzed oxidation (MCO), in which the reduced form of a protein-bound transition metal reacts with $\mathrm{H}_{2} \mathrm{O}_{2}$ to form a reactive intermediate in the immediate proximity of amino acid side chains (Stadtman and Levine, 2000). The reduction of - $\mathrm{SH}$ groups and consequently high levels of protein carbonyls in CA from Cd-alone treated plants (table 4) give good support for the above statement. In contrast, CA purified from $\mathrm{Zn}$-supplemented Cd treatments clearly showed restoration and perfect $\alpha$-helical conformation (table 4) similar to that of the native CA, indicating that $\mathrm{Zn}$ protects $\mathrm{CA}$ from $\mathrm{Cd}$-induced damage, restoring its original conformation and hence physiological function. $\mathrm{Zn}$ being catalytically associated as a co-factor of CA, necessary for its active functioning, competitively replaces $\mathrm{Cd}$ from the Cd-substituted enzyme active site thereby maintaining the spatial relationships with the different amino acid residues in the polypeptide backbone and hence the charge interactions favouring intact protein conformation (Pocker and Sarkanen, 


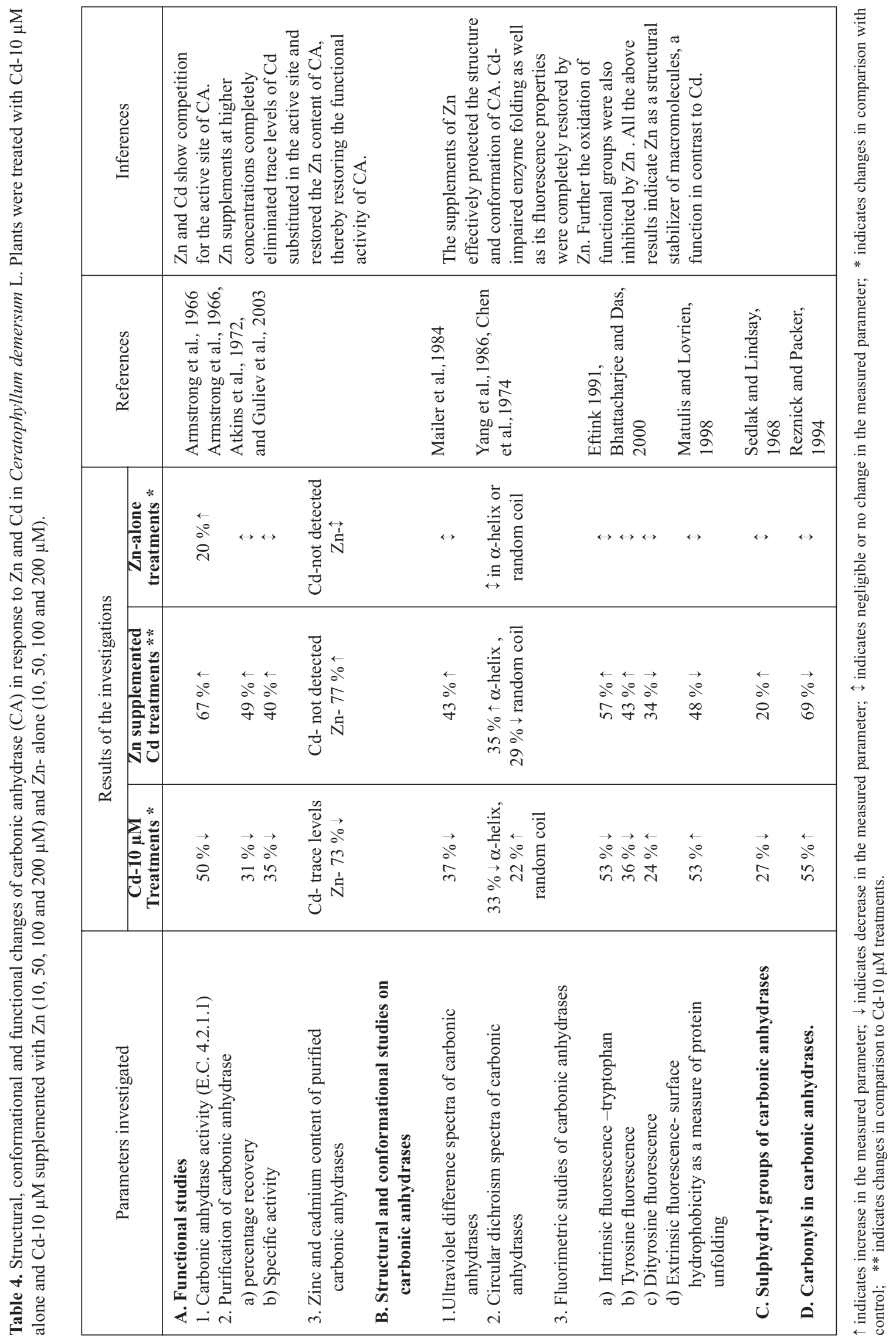


1978). Zn reduced carbonyl formation and maintained the thiol level in CA of Zn-supplemented Cd treatments indicating inhibition of side chain oxidations and sulphur group protection (Vallee and Falchuk, 1993; Zago and Oteiza, 2001). It can be suggested that Zn probably induces molecular "chaperones" which also prevent aggregation of the enzyme molecule and aid in proper protein folding (Rozema and Gellman, 1996). Loss of tryptophan and tyrosine fluorescence, plus the shift in emission maxima, were completely restored in $\mathrm{Cd}$ treatments with supplemented $\mathrm{Zn}$, indicating intact folded protein conformation. The formation of dityrosine (oxidized tyrosine) was also completely inhibited by supplementing $\mathrm{Zn}$ to $\mathrm{Cd}$ treatments. The protection of - $\mathrm{SH}$ groups from thiol oxidation by $\mathrm{Zn}$ in $\mathrm{Cd}$ treatments with supplemented $\mathrm{Zn}$ would have strengthened the Zn-metalloprotein interaction (Cakmak, 2000; Zago and Oteiza, 2001) and hence prevented formation of destructive dityrosine. 8-Anilino-1-naphthalene sulfonateprotein fluorescence was totally reduced to control levels in $\mathrm{CA}$ from $\mathrm{Zn}$-supplemented $\mathrm{Cd}$ treatments indicating protected hydrophobic regions in the intact and folded state of native CA, similar to that of the control. Zinc-alone treatments did not affect conformation, nor the fluorescence properties of native CA. Wolff et al. (1986) have previously indicated that $\mathrm{Zn}$ might play a crucial role in the decreased formation of oxidized products of protein. Since $\mathrm{Zn}$ possesses antioxidant properties (Girotti et al., 1985; Bray and Bettger, 1990; Powell, 2000; Zago and Oteiza, 2001), an inverse correlation may exist between $\mathrm{Zn}$ status and protein oxidation, with radical damage to proteins being accentuated by $\mathrm{Zn}$ deficiency (Cakmak, 2000). Our experiments with CA using mixed treatments of $\mathrm{Zn}$ and $\mathrm{Cd}$ conclusively proved the above statement that $\mathrm{Zn}$ counteracts the ROS-mediated oxidative attack on, proteins induced by $\mathrm{Cd}$ stress, further substantiating the role of $\mathrm{Zn}$ as an antioxidant.

e) Zn protects chloroplast photochemical functions from $\mathrm{Cd}$ toxicity: Metal ions are well known to affect the structure and function of chloroplasts in many plant systems such as Beta vulgaris (Greger and Ogren, 1991), Spinacea oleracea (Šeršeň and Král'ová, 2001), Triticum aestivum (Atal et al., 1991), and Zea mays (Prasad, 1995b). Reactive oxygen species directly affect the structure of the thylakoid membrane through peroxidation and oxidative stress. This alters the lipid composition of the thylakoid membranes leading to changes and disorganization (Stoyanova and Tchakalova, 1999) of the grana stacks with dilated thylakoid membranes observable as plastoglobules (Baszyński et al., 1980) This ultimately leads to the inactivation of oxygen-evolving centers and impaired electron transport (Krupa et al., 1994). Metal ions specifically inhibit chlorophyll biosynthesis through $\delta$-aminolevulinic acid dehydratase (ALA dehydratase) (Myśliwa-Kurdziel and Strzał ka, 2002) and protochlorophyllide reductase (Baszyński et al., 1980; Myśliwa-Kurdziel et al., 2004) through the oxidationprone - SH group leading to diminished production of 5aminolevulinic acid (ALA), the first common precursor for all the tetrapyrroles. In our study system of $C$. demersum $\mathrm{Cd}$ also drastically affected chlorophyll and carotenoid levels (table 5). On the other hand, when Cd-treated plants were supplemented with $\mathrm{Zn}$, there was full protection and restoration of the chlorophyll levels. Zinc probably maintains chlorophyll synthesis through $-\mathrm{SH}$ group protection of the oxidation-prone $\delta$-aminolevulinic acid dehydratase (ALA dehydratase) and protochlorophyllide reductase (Baszyński et al., 1980; Myśliwa-Kurdziel and Strzałka, 2002; MyśliwaKurdziel et al., 2004). Since ALA dehydratase catalyzing the conversion of ALA to porphobilinogen requires $\mathrm{Mg}^{2+}$ or $\mathrm{Zn}^{2+}$ for its efficient functioning (Beale, 1999), Zn possibly plays a role in activating this enzyme, and hence protochlorophyllide to chlorophyllide conversion facilitating the formation of the complete chlorophyll moiety. Our results clearly support not only the protection of chlorophyll but also an increase in chlorophyll indicating that $\mathrm{Zn}$ may be involved in furthering chlorophyll biosynthesis above the control level (table 5). Probably $\mathrm{Zn}$ also maintains the rate of synthesis of carotenoids in C. demersum. It has been reported that $\mathrm{Cd}$ affects the lipid structure around PSII, especially the light-harvesting chl $a / b$ protein complex II (Prasad, 1995b), leading to a loss of major fatty acids (Peters and Chin, 2003) and the production of lipid hydroperoxides thereby crippling the photosynthetic process. Cd-induced loss of intactness is clearly observed in our case (table 5). $\mathrm{Zn}$ on the other hand shows a clear restoration of the lost photosynthetic activity indicating its action against the toxic nature of $\mathrm{Cd}$. $\mathrm{Zn}$ is known to have a stabilizing and protective effect on biomembranes (Chvapil, 1973; Cakmak 2000). This, in addition to increased carotenoid synthesis triggered by $\mathrm{Zn}$, protects the thylakoid membrane from ROSmediated peroxidative damage and hence the loss of thylakoid proteins also, conclusively proved by our results of chloroplast intactness. $\mathrm{Cd}^{2+}$ ions have been reported to replace $\mathrm{Mn}^{2+}$ ions at the oxygen-evolving centers, the primary source of electrons from water to PSII, thereby inhibiting the reactions of PSII (Baszyński et al., 1980; Prasad, 1995b) and associated proteins of the PSII reaction centers, especially the D1 polypeptide. Cd complexes with aromatic amino acid residues like tryptophan 


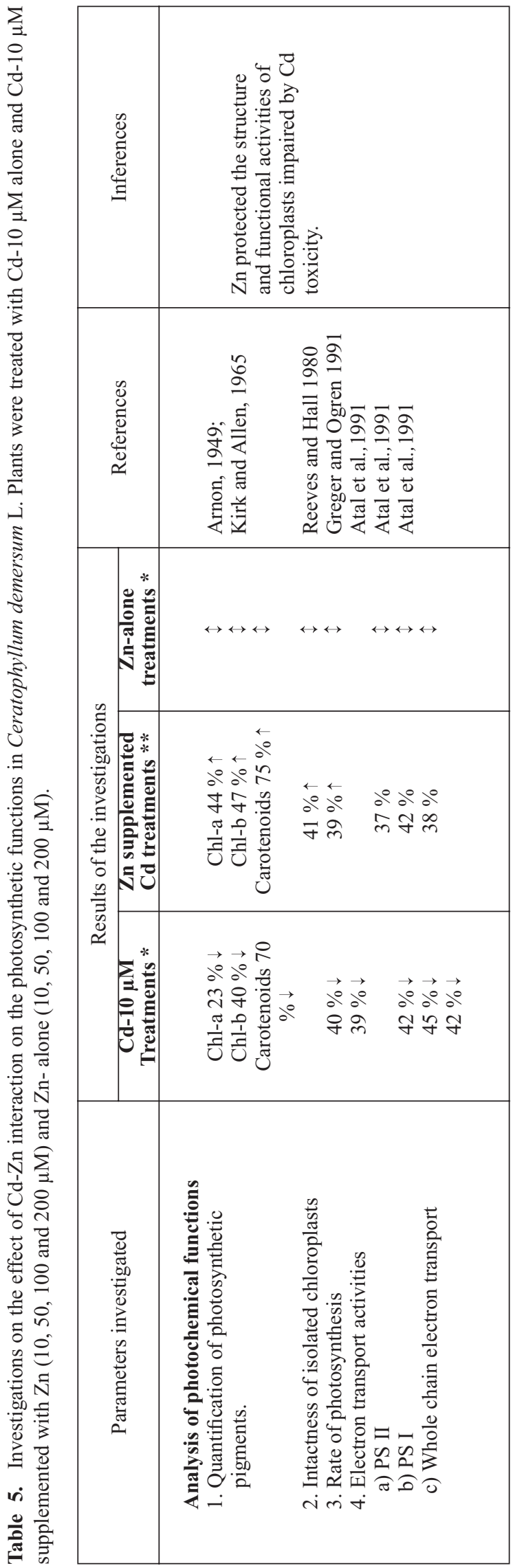

(Šeršeň and Král'ová, 2001) and PSII-D1 polypeptide. This Cd-D1 complex interferes with the degradation of D1 protein by a protease, a normal operation of the PS II reaction center, leading to impaired PS II activity (figure 6) (Hideg et al., 1994). This dysfunction propagates throughout the electron transport chain in the system. Zn, by controlling the levels of $\mathrm{Cd}$ entering into the system, controls its intracellular levels. Furthermore, the replacement of a toxic metal, Cd, by a physiologically active metal like $\mathrm{Zn}$, maintains the integrity at the oxygen-evolving centers and prevents oxidative burst at antenna chl molecules and binding of Cd to the major thylakoid proteins like D1 of PSII. An active PSII initiates a proper electron transport and hence an active functioning of PSI and the complete photophosphorylation process.

\section{Molecular aspects of $\mathrm{Zn}$ reversal of $\mathrm{Cd}$-induced damage to DNA integrity}

Nucleic acids are highly susceptible to metal-catalyzed oxidations with both nucleoside bases and sugar moieties being targets of ROS. The mediation of metal toxicity on DNA damage may be direct (Hossain and Huq, 2002a) or indirect in nature (Gichner et al., 2004). The toxicity of $\mathrm{Cd}$ on the structural integrity of DNA was identified utilizing the principle of the formation of a fluorescent complex between double-stranded DNA and ethidium bromide (EB) (Cai and Cherain, 2003). DNA, after exposure to the toxic levels of Cd $(10 \mu \mathrm{M})$, resulted in a distinct loss of fluorescence due to the decreased binding of EB with DNA (figures 5 and 6). Oxygen free radicals induce numerous lesions in DNA that cause

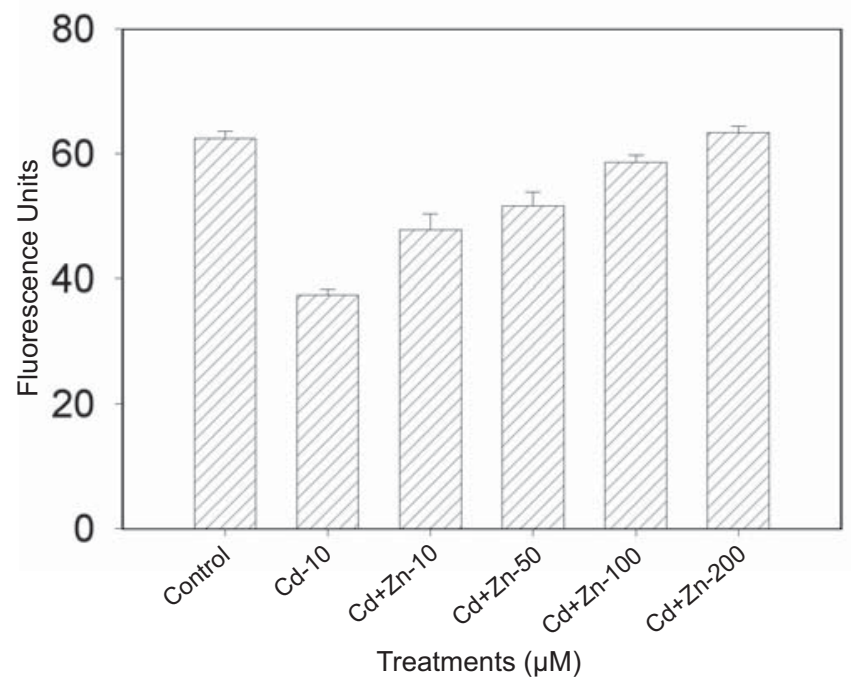

Figure 5. Ethidium bromide-DNA fluorescence as a measure of DNA damage in $C$. demersum plants treated with $\mathrm{Cd}-10 \mu \mathrm{M}$ and $\mathrm{Zn}$ (10, $50,100$ and $200 \mu \mathrm{M})$. Error bars represent standard errors and an 'asterisk' indicates significant difference from $\mathrm{Cd}$ treated plants. 
deletions, mutations and other lethal genetic effect (Breen and Murphy, 1995). The primary effect is the oxidation of the sugar moiety by the $\mathrm{OH} \cdot$ radical, in a metal-catalyzed reaction (the metal bound to DNA by chelation to the phosphodiester linkage), thereby leading to the oxidation of the adjacent sugar or nitrogenous base which in turn provokes a broad spectrum of DNA lesions (Halliwell and Gutteridge, 1990). The DNA lesions include DNA single- and double-strand breaks, apurinic/apyrimidinic sites, DNA-protein cross-links and base modifications (Hartwig and Schwerdtle, 2002). Fe and $\mathrm{Cu}$ are potent inducers of DNA damage especially in the presence of $\mathrm{H}_{2} \mathrm{O}_{2}$ while other metals like $\mathrm{Ni}, \mathrm{Cd}$ and $\mathrm{Co}$ are also reported to induce base modifications. Cross-linking of protein to DNA is another consequence of $\mathrm{OH} \cdot$ attack on either the DNA or protein. This generates covalent linkages such as thyminecysteine adducts making the DNA-protein inseparable and is lethal to the system if replication or transcription precedes the repair mechanism (Hartwig and Schwerdtle, 2002). DNA gel mobility assays also clearly determined the enhanced mobility of the DNA on the agarose gel due to loss of the double-stranded nature and fragmentation (Szuster-Ciesielska et al., 2000; Cai and Cherian, 2003) in DNA isolated from Cd$10 \mu \mathrm{M}$ treatments (figure 7) when compared with the intact DNA isolated from the control. First, direct binding of $\mathrm{Cd}$ to DNA bases (specifically G, A and T), the interaction of malondialdehyde with DNA and the interaction of Cd-induced ROS with DNA (Bhanoori and Venkateswerlu, 1998) all lead

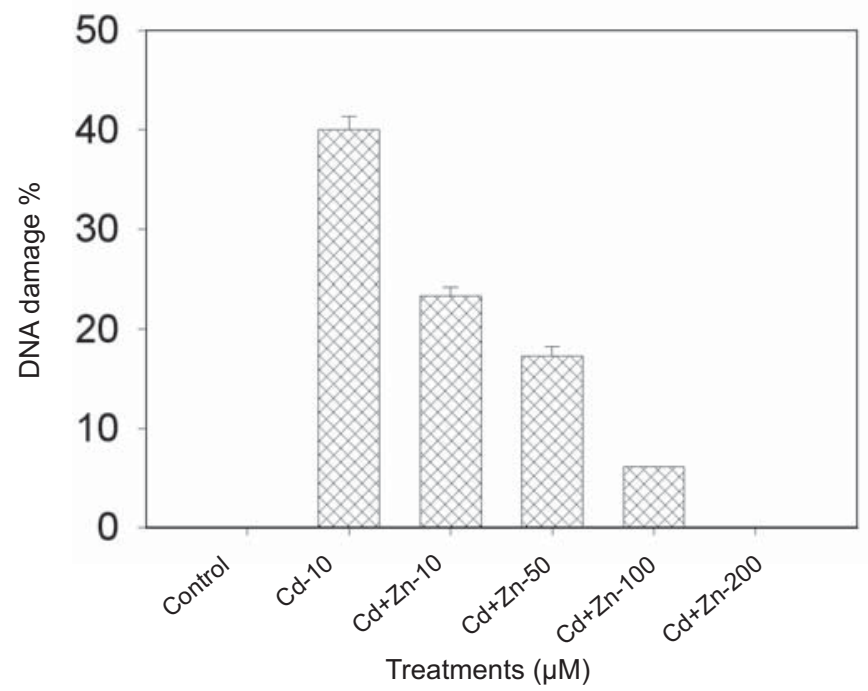

Figure 6. Levels of DNA damage in C. demersum plants treated with Cd-10 $\mu \mathrm{M}$ and $\mathrm{Zn}(10,50,100$, and $200 \mu \mathrm{M})$. Error bars represent standard errors and an 'asterisk' indicates significant difference from Cd treated plants. to extensive DNA damage. Second, metal ions are also known to inhibit the DNA repair processes (Hartwig and Schwerdtle, 2002). The DNA isolated from $\mathrm{Zn}$-supplemented $\mathrm{Cd}$ treatments showed complete restoration of the lost fluorescence of EBDNA interaction (figures 5 and 6) indicating intact structural integrity brought about by $\mathrm{Zn}$ ions favouring enhanced binding of EB with the DNA. Similarly, the DNA also showed complete inhibition of its mobility indicating the non-fragmentation of the DNA strands (figure 7). Zn ions act as the framework with which the folding of the domain is stabilized for a high affinity and site-specific binding of the double-stranded DNA (Klug and Rhodes, 1987; Wu and Wu, 1987). Zn ions were shown to inhibit DNA fragmentation and apoptosis induced by various stimuli in different animal and human systems (SzusterCiesielska et al., 2000; Cai and Cherian, 2003). Zn probably modulates the protection of DNA from Cd-induced damage either by inhibition of $\mathrm{Ca}^{2+} / \mathrm{Mg}^{2+}$-dependent endonuclease or by inhibiting metal catalyzed oxidative damage through $\mathrm{OH} \cdot$ attack on either the DNA or protein both by $-\mathrm{SH}$ group protection and inhibition of redox cycling of the associated metal ions thereby preventing the generation of covalent linkages such as thymine-cysteine adducts (Bray and Bettger, 1990; Ebadi et al., 1996). The latter seems to be the most probable mechanism in the present system of study.

Acknowledgements: PA is grateful to the Council of Scientific and Industrial Research (CSIR), New Delhi, India for the award of junior and senior research fellowships [F. No. 9/414

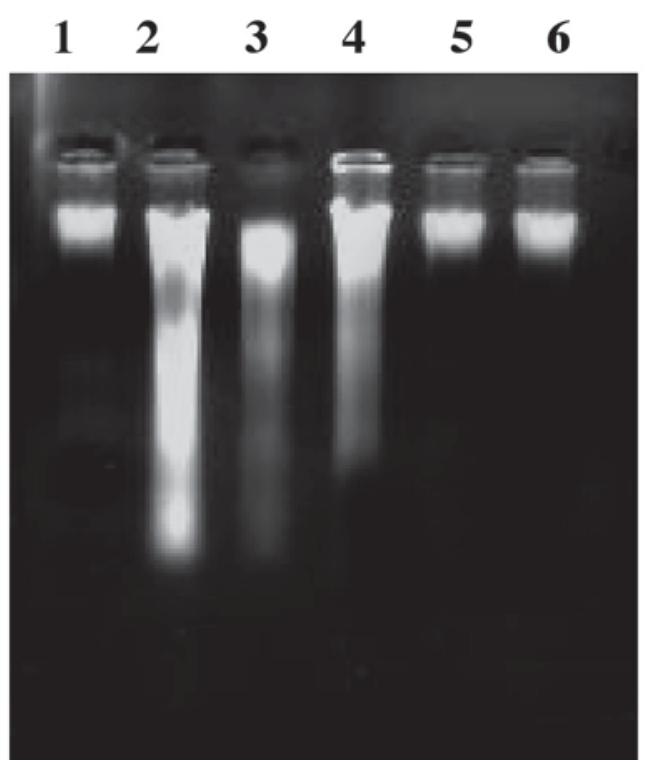

Figure 7. Agarose gel (1\%) showing the DNA mobility of DNAs isolated from $C$. demersum plants. Lanes 1: control, 2: Cd-10 $\mu \mathrm{M}, 3: \mathrm{Cd}+\mathrm{Zn}-10 \mu \mathrm{M}, 4: \mathrm{Cd}+\mathrm{Zn}-50 \mu \mathrm{M}, 5: \mathrm{Cd}+\mathrm{Zn}-100 \mu \mathrm{M}$, 6: $\mathrm{Cd}+\mathrm{Zn}-200 \mu \mathrm{M}$. 
(518)/2001-EMR]. Thanks are also due to the Department of Science and Technology, New Delhi for financial support (SP/ $\mathrm{SO} / \mathrm{A}-21 / 97$, dt. 1-7-1999).

\section{REFERENCES}

Adriano DC (2001) Trace elements in terrestrial environments: Biogeochemistry, bioavailability, and risks of metals. $2^{\text {nd }}$ edn. Springer-Verlag, New York.

Alscher RG, Donahue JL, Cramer CL (1997) Reactive oxygen species and antioxidants: relationships in green cells. Physiol. Plant. 100:224-233.

Anabel M, Bueno P, Carmen Marín M, Rodríguez-Rosales MP, Belver A, Venema K, Donaire JP (2002) Involvement of endogenous salicylic acid content, lipoxygenase and antioxidant enzyme activities in the response of tomato cell suspension cultures to NaCl. New Phytol. 156:409-415.

Anfinsen CB (1973) Principles that govern the folding of protein chains. Science 181:223-230.

Aravind P, Prasad MNV (2003) Zinc alleviates cadmium-induced oxidative stress in Ceratophyllum demersum L.: A free floating freshwater macrophyte. Plant Physiol. Biochem. 41:391-397.

Aravind P, Prasad MNV (2004a) Carbonic anhydrase impairment in cadmium- treated Ceratophyllum demersum L. (free floating freshwater macrophyte): toxicity reversal by zinc. J. Anal. Atom. Spectrom. 19:52-57.

Aravind P, Prasad MNV (2004b) Zinc protects chloroplasts and associated photochemical functions in cadmium exposed Ceratophyllum demersum L.: A freshwater macrophyte. Plant Sci. 166:1321-1327.

Armstrong JMCD, Myers DV, Verpoorte JA, Edsall JT (1966) Purification and properties of human erythrocyte carbonic anhydrases. J. Biol. Chem. 241:5137-5149.

Arnon DI. (1949) Copper enzymes in isolated chloroplasts. Polyphenoloxidase in Beta vulgaris. Plant Physiol. 24; $1-15$.

Atal N, Pardhasaradhi P, Mohanty P (1991) Inhibition of chloroplast photochemical reactions by treatment of wheat seedlings with low concentrations of cadmium: Analysis of electron transport activities and changes in fluorescence yield. Plant Cell Physiol. 32:943-951.

Atkins CA, Patterson BD, Graham D (1972) Plant carbonic anhydrases. Distribution of types among species. Plant Physiol. 50:214-223.

Babbs CF, Gale MJ (1987) Colorimetric assay for methanesulfinic acid in biological systems. Anal. Biochem. 163:67-73.

Badger MR (1987) The CO2 concentrating mechanism in aquatic phototrophs In: Hatch MD, Boardman NK (eds), The biochemistry of plants: a comprehensive treatise, Volume X, pp. 219-274. Academic press, New York.

Badger MR, Price GD (1994) The role of carbonic anhydrase in photosynthesis. Annu. Rev. Plant Physiol. Plant Mol. Biol. 45:369-392.

Baker AJM (1981) Accumulators and excluders- strategies in the response of plants to heavy metals. J. Plant Nutr. 3: 643-654.

Baszyński T, Wajda L, Krol M, Wolińska D, Krupa Z, Tuken- dorf A (1980) Photosynthetic activities of cadmium-treated tomato plants. Physiol. Plant. 48:365-370.

Beale SI (1999) Enzymes of chlorophyll biosynthesis. Photosynth. Res. 60:43-73.

Beauchamp C, Fridovich I. (1971) Superoxide dismutase: improved assays and an assay applicable to acrylamide gels. Anal. Biochem. 44:276-287.

Bereczky Z, Wang HY, Schubert V, Ganal M, Bauer P (2003) Differential regulation of Nramp and IRT transporter genes in wild type and iron uptake mutants of tomato. J. Biol. Chem. 278:24697-24704.

Best EPH (1986) Photosynthetic characteristics of the submerged macrophyte Ceratophyllum demersum. Physiol. Plant. 68:502-510

Best EPH, Meulemans TJ (1979) Photosynthetic characteristics of the submerged macrophyte Ceratophyllum demersum. Aquat. Bot. 6:53-65 C.E.B.A.S. workshop.

Bhanoori M, Venkateswerlu G (1998) The alkaline single strand cell electrophoresis: a new test for assessing DNA strand breaks in Neurospora crassa. Mut. Res. 405:29-34.

Bhattacharjee C, Das KP (2000) Thermal unfolding and refolding of $\beta$-lactoglobulin: an intrinsic and extrinsic fluorescence study. Eur. J. Biochem. 267:3957-3964.

Bray TM, Bettger WJ (1990) The physiological role of zinc as an antioxidant. Free Rad. Biol. Med. 8:281-291.

Breen AP, Murphy JA (1995) Reactions of oxy radicals with DNA. Free Rad. Biol. Med. 18:1033-1077.

Cai L, Cherian G (2003) Zinc-metallothionein protects from DNA damage induced by radiation better than glutathione and $\mathrm{Cu}-$ or Cd- metallothioneins. Toxicol Lett. 136:193-198.

Cakmak I (2000) Possible roles of zinc in protecting plant cells from damage by reactive oxygen species. New Phytol. 146:185-205.

Cakmak I, Braun HJ (2001) Genotypic variation for zinc efficiency. In: Reynolds MP, Ortiz-Monasterio JI, McNab A (eds), Application of physiology in wheat breeding, pp. 183-199, Mexico, D.F. CIMMYT.

Cakmak I, Marschner H (1998a) Increase in membrane permeability and exudation in roots of Zn-deficient plants. J. Plant Physiol. 132:356-361.

Cakmak I, Marschner H (1998b) Enhanced superoxide radical production in roots of $\mathrm{Zn}$-deficient plants. J. Exp. Bot. 39:1449-1460.

Cakmak I, Marschner H (1993) Effect of zinc nutritional status on activities of superoxide radical and hydrogen peroxide scavenging enzymes in bean leaves. Plant Soil. 155/156:127-130.

Cakmak I, Ozturk L, Eker S, Torun B, Kalfa HI, Yilmaz A (1997) Concentration of $\mathrm{Zn}$ and activity of copper/zinc superoxide dismutase in leaves of rye and wheat cultivars differing in sensitivity to zinc deficiency. J. Plant Physiol. 151:91-95.

Cakmak I, Marschner H (1988c) Zinc-dependent changes in ESR signals, NADPH oxidase and plasma membrane permeability in cotton roots. Physiol. Plant. 73:182-186.

Cakmak I, Marschner H, Bangerth F (1989) Effect of zinc nutritional status on growth, protein metabolism and levels of indole-3-acetic acid and other phytohormones in bean (Phaseolus vulgaris L.). J. Exp. Bot. 40:405-412. 
Casano LM, Gomez LD, Lascano HR, Gonzalez CA, Trippi VS (1997) Inactivation and degradation of $\mathrm{Cu} / \mathrm{Zn}-\mathrm{SOD}$ by active oxygen species in wheat chloroplasts exposed to photooxidative stress. Plant Cell Physiol. 38:433-440.

Cataldo DA, Garland TR, Wildung RE(1983) Cadmium uptake kinetics in intact soyabean plants. Plant Physiol. 73:844-848.

Chance B, Maehly AC (1955) Assay of catalases and peroxidases. Methods Enzymol. 2:764-775.

Chaoui A, Ghorbal MH, Ferjani EE (1997) Effects of cadmium-zinc interactions on hydroponically grown bean (Phaseolus vulgaris L.). Plant Sci. 126:21-28.

Chen WP, Li PH (2001) Chilling-induced $\mathrm{Ca}^{2+}$ overload enhances production of active oxygen species in maize (Zea mays L.) cultured cells: the effect of abscisic acid treatment. Plant Cell Environ. 24:791-800.

Chen YH, Yang JT, Chau KH (1974) Determination of the helix and $\beta$ form of proteins in aqueous solution by circular dichroism. Biochemistry 13:3350-3359.

Chvapil M (1973) New aspects in the biological role of zinc: a stabilizer of macromolecules and biological membranes. Life Sci. 13:1041-1049.

Conklin PL, Lasat RL (1995) Differential accumulation of antioxidant mRNAs in Arabidopsis thaliana exposed to ozone. Plant Physiol. 19:202-212.

Costa G, Morel JL (1994) Efficiency of $\mathrm{H}^{+}$ATPase activity on Cd uptake by four cultivars of lettuce. J. Plant Nutr. 17:627-637.

Creighton TE (1993) Proteins: structure and molecular properties, pp. 1-48. WH Freeman and company, New York.

Das P, Samantaray S, Rout GR (1997) Studies on cadmium toxicity in plants: a review. Environ. Pollut. 98:29-36.

Davies MJ (2003) Singlet oxygen-mediated damage to proteins and its consequences. Biochem. Biophys. Res. Commun. 305:761-770.

De AK (1992) Cadmium, the polluter around us. Sci. Rep. 29:19-21.

De Tullio MC, Gara LD, Paciolla C, Arrigoni O (1998) Dehydroascorbate-reducing proteins in maize are induced by the ascorbate biosynthesis inhibitor lycorine. Plant Physiol. Biochem. 36:433-440.

De Gara L, Paciolla C, De Tullio MC, Motto M, Arrigioni, O (2000) Ascorbate-dependent hydrogen peroxide detoxification and ascorbate regeneration during germination of a highly productive maize hybrid: evidence of an improved detoxification mechanism against reactive oxygen species. Physiol. Plant. 109:7-13.

Devi SR, Prasad MNV (1998) Copper toxicity in Ceratophyllum demersum L. (Coontail), a free floating macrophyte: Response of antioxidant enzymes and antioxidants. Plant Sci. 138:157-165.

Devi M, Thomas DA, Barber JT, Fingerman M (1996) Accumulation and physiological and biochemical effects of cadmium in a simple aquatic food chain. Ecotox. Environ. Safety 33:38-43.

DrażKiewicz M, Skórzyńska-Polit E, Krupa Z (2003) Response of ascorbate-glutathione cycle to excess copper in Arabidopsis thaliana (L.). Plant Sci. 164:195-202.

Drotar A, Phelps P, Fall R (1985) Evidence for glutathione peroxidase activites in cultured plant cells. Plant Sci. 42:35-40.
Ebadi M, Leuschen MP, El Refaey H, Hamada FM, Rojas $P$ (1996) The antioxidant properties of zinc and metallothionein. Neurochem. Int. 29:159-166.

Ederli L, Pasqualini S, Batini P, Antonielli M (1997) Photoinhibition and oxidative stress: effects on xanthophyll cycle, scavenger enzymes and abscissic acid content in tobacco plants. J. Plant Physiol. 151:422-428.

Eftink MR (1991) Fluorescence techniques for studying protein structure. Methods Biochem. Anal. 35:127-205.

Eide D (1997) Molecular biology of iron and zinc uptake in eukaryotes. Curr. Opin. Cell Biol. 9:573-577.

Elzenga JTM, Prins HBA (1988) Adaptation of Elodea and Potamogeton to different inorganic carbon levels and the mechanism for photosynthetic bicarbonate utilization. Aust. J. Plant Physiol. 15:727-735.

Fleschin S, Fleschin M, Nita S, Pavel E, Magearu V (2000) Free radicals mediated protein oxidation in biochemistry. Roum. Biotechnol. Lett. 5:479-495.

Fodor E, Szabo-Nagy A, Erdei L(1995) The effects of cadmium on the fluidity and $\mathrm{H}^{+}$ATPase activity of plasma membrane from sunflower and wheat roots. J. Plant. Physiol. 147:87-92.

Fox TC, Guerinot ML (1998) Molecular biology of cation transport in plants. Annu. Rev. Plant Physiol. Plant Mol. Biol. 49:669-696.

Foyer CH, Halliwell B (1976) The presence of glutathione and glutathione reductase in chloroplasts: A proposed role in ascorbic acid metabolism. Planta 133:21-25.

Foyer CH, Theodoulou F, Delrot S (2001) The functions of inter- and intracellular glutathione transport systems in plants. Trends Plant Sci. 6:486-492.

Garg P, Chandra P (1990) Toxicity and accumulation of chromium in Ceratophyllum demersum L. Bull. Environ. Contam. Toxicol. 44:473-478.

Gibson TS, Leece DR (1981) Estimation of physiologically active zinc in maize by biochemical assay. Plant Soil 63:395-406.

Gichner T, Patková Z, Száková J, Demnerová K (2004) Cadmium induces DNA damage in tobacco roots, but no DNA damage, somatic mutations or homologous recombination in tobacco leaves. Mut. Res. 49-57.

Girotti AW, Thomas JP, Jordan JE (1985) Inhibitory effect of $\mathrm{Zn}$ (II) on free radical lipid peroxidation in erythrocyte membranes. Free Rad. Biol. Med. 1:395-401.

Goering PL, Waalkes MP, Klaausen CD (1994) Toxicology of metals, biochemicals, In: Handbook of experimental pharmacology, 115: pp. 189-214 Springer, New York.

Greger M, Ogren E (1991) Direct and indirect effects of $\mathrm{Cd}^{2+}$ on photosynthesis in sugarbeet (Beta vulgaris). Physiol. Plant. 83:129-135.

Grotz N, Fox T, Connolly E, Park W, Guerinot ML, Eide D (1998) Identification of a family of zinc transporter genes from Arabidopsis that respond to zinc deficiency. Proc. Natl. Acad. Sci. USA 95:7220-7225.

Guliev NM, Bairamov SHM, Aliev DA (1992) Functional organization of carbonic anhydrase in higher plants. Sov. Plant Physiol. 39:537-544.

Guliev NM, Babaev GV, Bairamov SHM, Aliev DA (2003) Purification, properties and localization of two carbonic anhydrases from Amaranthus curentus leaves. Russ. J. Plant Physiol. 50:213-229. 
Habig, WH, Jakoby WB (1981) Assay for differentiation of glutathione-S-transferase. Methods in Enzymol. 77:398-405.

Hadjiliadis ND (1997) Cytotoxic, mutagenic and carcinogenic potential of heavy metals related to human environment, NATO ASI series, Vol. 26, Kluwer Academic, Netherlands.

Halliwell B, Gutteridge JMC (1990) Role of free radicals and catalytic metal ions in human disease: an overview. Methods Enzymol. 186:1-85.

Hartwig A, Schwerdtle T (2002) Interactions by carcinogenic metal compounds with DNA repair processes: toxicological implications. Toxicol. Lett. 127:47-54.

He QB, Singh BR (1994) Crop uptake of cadmium from phosphorus fertilizers. I. Yield and cadmium content. Water Air Soil Pollut. 74:251-265.

Heath RL, Packer L (1968) Photoperoxidation in isolated chloroplasts 1 . Kinetics and stoichiometry of fatty acid peroxidation. Arch. Biochem. Biophys. 125:189-198.

Hideg E, Spetea C, Vass I (1994) Singlet oxygen and free radical production during acceptor- and donor- side induced photoinhibition. Studies with spin trapping EPR spectroscopy. Biochim. Biophys. Acta 1186:143-152.

Hissin PJ, Hilf R (1976) A fluorimetric method for determination of oxidized and reduced glutathione in tissues. Anal. Biochem. 74:214-226.

Holländer-Czytko H (1994b) Nitrate uptake and the physiology of the water plant Ceratophyllum demersum. (Abstr) Plant Physiol 195:39 Suppl,

Hossain B, Hirata A, Nagatomo Y, Akashi R, Takaki H (1997) Internal zinc accumulation is correlated with increased growth in rice suspension culture. J. Plant Growth Regul. 16:239-243.

Hossain Z, Huq F (2002) Studies on the interaction between $\mathrm{Cd}^{2+}$ ions and DNA. J. Inorg. Biochem. 90:85-96.

International Agency for Research on Cancer (IARC) (1993) Beryllium, cadmium, mercury and exposures in glass manufacturing industry, In: IARC monographs on the evaluation of carcinogenic risks to humans, pp. 41-117, 58: Lyon.

Jiang M, Zhang J (2001) Effect of abscissic acid on active oxygen species, antioxidative defense system and oxidative damage in leaves of maize seedlings. Plant Cell Physiol. 42:1265-1273.

Kabata-Pendias A (2001) Trace elements in soils and plants, CRC Press, Boca Raton.

Kawano T, Kawano N, Muto S, Lapeyrie F (2001) Cationinduced superoxide generation in tobacco cell suspension culture is dependent on ion valence. Plant Cell Environ. 24:1235-1241.

Keskinkan O, Goksu MZL, Basibuyuk M, Forster CF (2004) Heavy metal adsorption properties of a submerged aquatic plant (Ceratophyllum demersum) Bioresour. Technol. 92:197-200.

Kirk JTO, Allen RL. (1965) Dependence of chloroplast pigment synthesis on protein synthesis: effect of actidone. Biochem. Biophys. Res. Commun. 21; 523-530.

Klug A, Rhodes D (1987) 'Zinc fingers': a novel protein motif for nucleic acid recognition. Trends Biochem. Sci. 12: 464-469.
Kochian LV (1993) Zinc absorption from hydroponic solutions by plant roots. In: Robson AD (ed), Zinc in Soils and Plants, pp. 45-57. Kluwer, Academic Publishers, Boston/ Dordrecht.

Koleli N, Eker S, Cakmak I (2004) Effect of zinc fertilization on cadmium toxicity in durum and bread wheat grown in zinc-deficient soil. Environ. Pollut. 131:453-459.

Krupa Z, Öquist G, Huner NPA (1994) The effects of cadmium on photosynthesis of Phaseolus vulgaris-a fluorescence analysis. Physiol. Plant. 88:626-630.

Kumar GP and Prasad MNV (2004a) Cadmium toxicity to Ceratophyllum demersum L. (a freshwater macrophyte): morphological symptoms, membrane damage and ion leakage. Bull. Environ. Contam. Toxicol. 72:1038-1045.

Kumar GP and Prasad MNV (2004b) Cadmium-inducible proteins in Ceratophyllum demersum L. (a fresh water macrophyte): toxicity bioassays and relevance to cadmium detoxification. Bull. Environ. Contam. Toxicol. 73:174-181.

Lane TW, Morel FMM (2000) Regulation of carbonic anhydrase expression by zinc, cobalt and carbon dioxide in the marine diatom Thalassiosira weissflogii. Plant Physiol. 123:345-352.

Lasat MM, Pence NS, Garvin DF, Ebbs SD, Kochain LV (2000) Molecular physiology of zinc transport in the Zn hyperaccumulator Thlaspi caerulescens. J. Exp. Bot. 51:71-79.

Li B, Blough NV, Gutierrez PL (2000) Trace detection of hydroxyl radicals during the redox cycling of low concentrations of diazoquone: a new approach. Free Rad. Biol. Med. 29:548-556.

Logan BA, Grace SC, Adams WW, Adams BD (1998) Seasonal differences in xanthophylls cycle characteristics and antioxidants in Mahonia repens growing in different light environments. Oecologia 116:9-17.

Lowry OH, Rosenberg NJ, Farr AL, Randall RJ (1951) Protein measurement with folin phenol reagent. J. Biol. Chem. 193:265-275.

Luna CM, Gonzalez CA, Tripp VS (1994) Oxidative damage caused by excess of copper in oat leaves. Plant Cell Physiol. 35:11-15.

Mailer K, Calhoun LA, Livesey DL. (1984) Ultraviolet difference spectroscopy of bovine carbonic anhydrase with various divalent metals. J. Inorg. Biochem. 20:93-102.

Marrs KA (1996) The functions and regulation of glutathioneS-transferase in plants. Annu. Rev. Plant Physiol. Plant Mol. Biol. 47:127-158.

Marschner H (1995) Mineral nutrition of higher plants, $2^{\text {nd }}$ edn. Academic press, London.

Marschner H, Romheld V (1991) Function of micronutrients in plants: In: Mortvedt JJ, Cox FR, Shuman LM, Welch RM, (eds), Micronutrients in agriculture, $2^{\text {nd }}$ Edn, pp. 297-328. SSSA, Inc., Madison, WI.

Matulis D, Lovrien R (1998) 8-Anilino-1-naphthalene sulfonate anion-protein binding depends primarily on ion pair formation. Biophys. J. 74:422-429.

Mazhoudi S, Chaoui A, Ghorbal MH, Ferjani EE (1997) Response of antioxidant enzymes to excess copper in tomato (Lycopersicon esculentum Mill.). Plant Sci. 127:129-137.

McCall KA, Huang CC, Fierke CA (2000) Function and mechanism of zinc metalloenzymes In: Zinc and health: current 
status and future directions. American Society for Nutritional Sciences. Supplement 1437s-1446s.

McKenna IM, Chaney RL, Williams FM (1993) The effects of cadmium and zinc interactions on the accumulation and tissue distribution of zinc and cadmium in lettuce and spinach. Environ. pollut. 79:113-120.

Michelet B, Boutry M (1995) The plasma membrane $\mathrm{H}^{+}$-ATPase. Plant Physiol.108:1-6.

Miszalski Z, Slesak I, Niewiadomska E, Baczek-Kwinta R, Luttge U, Ratajczak R (1998) Subcellular localization and stress responses of superoxide dismutase isoforms from leaves in the $\mathrm{C}_{3}$-CAM intermediate halophyte Mesembryanthum crystallinum L. Plant Cell Environ. 21:169-179.

Morsomme P, Boutry M (2000) The plant plasma membrane $\mathrm{H}^{+}$-ATPase: structure, function and regulation. Biochim. Biophys. Acta. 1465:1-16.

Mukherjee SP, Choudhari MA (1983) Implications for water stress-induced changes in the levels of endogenous ascorbic acid and hydrogen peroxide in Vigna seedlings. Physiol. Plant. 58:166-170.

Myśliwa-Kurdziel B, Prasad MNV, Strzałka K (2004) Photosynthesis in metal stressed plants. In: Prasad MNV (ed), Heavy metal stress in plants: from biomolecules to ecosystems, $2^{\text {nd }}$ edn, pp. 146-181, Springer-Verlag, Heidelberg, Narosa, New Delhi.

Myśliwa-Kurdziel B, Strzałka K (2002) Influence of metals on the biosynthesis of photosynthetic pigments, In: Prasad MNV, Strzałka K (eds), Physiology and biochemistry of metal toxicity and tolerance in plants, pp. 201-228, Kluwer Academic, Dordrecht, Netherlands.

Nagalakshmi N, Prasad MNV (2001) Reponses of glutathione cycle enzymes and glutathione metabolism to copper stress in Scenedesmus bijugatus. Plant Sci. 160:291-299.

Nakano Y, Asada K (1981) Hydrogen peroxide is scavenged by ascorbate-specific peroxidase in spinach chloroplasts. Plant Cell Physiol. 22:867-880.

Nan Z, Li J, Zhang J, Cheng G (2002) Cadmium and Zinc interactions and their transfer in soil-crop system under actual field conditions. Sci. Total Environ. 285:187-195.

Nieboer E, Richardson DHS (1980) The replacement of the non-descriptive term "heavy metals" by a biologically and chemically significant classification of metal ions. Environ. Pollut. Ser. B 1:3-26.

Noctor G, Arisi AC, Jouanin L, Kunert KJ, Rennenberg H, Foyer CH (1998) Glutathione: biosynthesis, metabolism, and relationship to stress tolerance explored in transformed plants. J. Exp. Bot. 49:623-647.

Ornes WH, Sajwan KS (1993) Cadmium accumulation and bioavailability in coontail (Ceratophyllum demersum L.) plants. Water Air Soil Pollut. 69:291-300.

Pallanca JE, Smirnoff N (2000) The control of ascorbate synthesis and turnover in pea seedlings. J. Exp. Bot. 51: 669-674.

Peraza MA, Fierro FA, Barber DS, Casarez E, Rael LT (1998) Effects of micronutrients on metal toxicity. Environ. Health Perspect. 106 (Suppl 1):203-216.

Peters JS, Chin SK (2003) Inhibition of photosynthetic electron transport by palmitoleic acid is partially correlated by the loss of thylakoid membrane proteins. Plant Physiol. Biochem. 41:117-214.
Prasad AS (1995) Zinc: an overview. Nutrition 11:93-99.

Prasad MNV (1995a) Cadmium toxicity and tolerance to vascular plants. Environ. Exp. Bot. 35:525-545.

Prasad MNV (1995b) Inhibition of maize leaf chlorophylls, carotenoids and gas exchange functions by cadmium. Photosynthetica 31:635-640.

Prasad MNV (2004a) Heavy metal stress in plants: from biomolecules to ecosystems, $2^{\text {nd }}$ ed, Springer-Verlag, Heidelberg, Narosa, New Delhi.

Prasad MNV (2004b) Phytoremediation of metals in the environment for sustainable development. Proc. Indian. Natn. Sci. Acad. B70 1:71-98.

Prasad MNV, Greger M, Smith BN (2001) Aquatic macrophytes In: Prasad MNV (ed), Metals in the environment- Analysis by biodiversity, p. 259-283. Marcel Dekker Inc., New York.

Prasad MNV, Strzałka K (2002) Physiology and biochemistry of metal toxicity and tolerance in plants. Kluwer Academic, Dordrecht.

Pocker Y, Sarkanen S (1978) Carbonic anhydrase: structure, catalytic versatility and inhibition. Adv. Enzymol. 47:149-274.

Poole RJ (1978) Energy coupling for membrane transport. Annu. Rev. Plant Physiol. 29:437-460.

Portillo F (2000) Regulation of plasma membrane $\mathrm{H}^{+}$ATPase in fungi and plants. Biochim. Biophys. Acta. 1469:31-42.

Powell SR (2000) The antioxidant properties of zinc. J. Nutr. 130:1447-1454.

Rai UN, Sinha S, Tripathi RD, Chandra P (1995) Waste water treatability potential of some aquatic macrophytes: Removal of heavy metals. Ecol. Eng. 5:5-12.

Rauser WE (2000) The role of thiols in plants under metal stress. In: Brunold C, Rennenberg H, DeKok LJ, Stulen LJ, Davidian JC (eds) Sulfur nutrition and sulfur assimilation in higher plants, pp. 169-183. Paul Haupt, Bern, Switzerland.

Reugsegger A, Schmutz D, Brunold C (1992) Effect of cadmium on $\gamma$-glutamylcysteine synthesis in maize seedlings. Plant Physiol. 99:428-433.

Reeves SG, Hall DO (1980) Higher plant chloroplasts and granas: general preparative procedures (excluding high carbon dioxide fixation ability chloroplasts). Methods Enzymol. 69:85-104.

Reznick AZ, Packer L (1994) Oxidative damage to proteins: spectrophotometric method for carbonyl assay. Methods Enzymol. 233:357-363.

Rivai IF, Koyama H, Suzuki S (1990) Cadmium content in rice and rice field soils in China, Indonesia and Japan, with reference to soil type and daily intake from rice. Jap. J. Health Human Ecol. 56:168-177.

Ross SM (1994) Toxic metals in soil plant systems. Wiley, Chichester, UK.

Rozema D, Gellman SH (1996) Artificial chaperone-assisted refolding of carbonic anhydrase B. J. Biol. Chem. 271: 3478-3487.

Saygideger S, Dogan M (2004) Lead and cadmium accumulation and toxicity in the presence of EDTA in Lemna minor L. and Ceratophyllum demersum L. Bull. Environ. Contam. Toxicol. 73:182-189.

Schǘtzendǘbel A, Polle A (2002) Plant responses to abiotic stresses: heavy metal-induced oxidative stress and protection by mycorrhization. J. Exp. Bot. 53:1351-1365. 
Sedlak J, Lindsay RH (1968) Estimation of total, proteinbound, and non-protein sulfhydryl groups in tissue by Ellman's reagent. Anal.Biochem. 25:192-208.

Šeršeń F, Král'ová K (2001) New facts about $\mathrm{CdCl}_{2}$ action on the photosynthetic apparatus of spinach chloroplasts and its comparison with $\mathrm{HgCl}_{2}$ action. Photosynthetica 39:575-580.

Shaw BP, Sahu SK, Mishra RK (2004) Heavy metal induced oxidative damage in terrestrial plants. In: Prasad MNV (ed), Heavy metal stress in plants- from biomolecules to ecosystems, $2^{\text {nd }}$ edn, pp. 84-126. Springer-Verlag, Narosa, New Delhi.

Sherlock JC (1986) Cadmium in foods and diet. In: Cadmium in the environment. Experientia supplementum, 50:p.110.

Siedlecka A (1995) Some aspects of interactions between heavy metals and plant mineral nutrients. Acta Soc. Bot. Pol. 3:265-272.

Smilde KW, Luit BW, Driel WV (1992) The extraction of soil and absorption by plants of applied zinc and cadmium. Plant Soil. 143:233-238.

Smirnoff N, Conklin PL, Loewus FA (2001) Biosynthesis of ascorbic acid in plants: a renaissance. Annu. Rev. Plant Physiol. Plant Mol. Biol.52:437-468.

Smith KS, Ferry JG (2000) Prokaryotic carbonic anhydrases. FEMS Microbiol. Rev. 24:335-366.

Smith IK, Vierheller TL, Thorne CA (1989) Properties and functions of glutathione reductase in plants. Physiol. Plant. 77:449-456.

Solioz M, Vulpe C (1996) CPx-type ATPases: a class of Ptype ATPases that pump heavy metals. Trends Biochem. Sci. 21:237-241.

Souza-Santos P, Ramos RS, Ferreira ST, Carvalho-Alves PC (2001) Iron-induced oxidative damage of corn root plasma membrane $\mathrm{H}^{+}$ATPase. Biochim. Biophys. Acta. 1512:357-366.

Stadtman ER, Levine RL (2000) Protein oxidation. Ann. N. Y. Acad. Sci. 899:191-208.

Stoyanova D, Tchakalova T (1999) Cadmium induced ultrastructural changes in shoot apical meristem of Elodea Canadensis Rich. Photosynthetica 37:47-52.

Suckcharoen S (1979) Ceratophyllum demersum as an indicator of mercury contamination in Thailand and Finland. Annales Botan. Fenn. 16:173-175.

Sultmeyer D, Schmidt C, Fock HP (1993) Carbonic anhydrases in higher plants and aquatic microorganisms. Physiol. Plant. 88:179-190.

Symeonidis L, Karataglis S (1992) Interactive effects of cadmium, lead and zinc on root growth of two metal tolerant genotypes of Holcus lanatus L. Biometals 5:173-178.

Szuster-Ciesieslska A, Stachura A, Słotwinska M, Kamiłska T, Snieżka R, Paduch R, Abramczyk D, Filar J, Kandefer-Szerszeń M (2000) The inhibitory effect of zinc on cadmiuminduced cell apoptosis and reactive oxygen species (ROS) production in cell cultures. Toxicology 145:159-171.

Taylor GJ (1989) Multiple metal stress in Triticum aestivum L., differentiation between additive, antagonistic, and synergistic effects. Can. J. Bot. 67:2272-2276.
Thys C, Vanthomme P, Schrevens E, De Proft M (1991) Interactions of $\mathrm{Cd}$ with $\mathrm{Zn}, \mathrm{Cu}, \mathrm{Mn}$, and Fe for lettuce ( $\mathrm{Lac}$ tuca sativa L.) in hydroponic culture. Plant Cell Environ. 14:713-717.

Tripathi RD, Rai UN, Gupta M, Yunus M, Chandra P (1995) Cadmium transport in submerged macrophyte Ceratophyllum demersum L. in presence of various metabolic inhibitors and calcium channel blockers. Chemosphere 31: 3783-3791.

Tripp BC, Smith K, Ferry JG (2001) Carbonic anhydrase: new insights for an ancient enzyme. J. Biol. Chem. 276: 48615-48618.

Trivedi S, Erdei L (1992) Effects of cadmium and lead on the accumulation of $\mathrm{Ca}^{2+}$ and $\mathrm{K}^{+}$and on the influx and translocation of $\mathrm{K}^{+}$in wheat of low and high $\mathrm{K}^{+}$status. Physiol. Plant. 84:94-100.

Vallee BL, Auld DS (1990) Zinc coordination, function and structure of zinc enzymes and other proteins. Biochemistry 29:5647-5659.

Vallee BL, Falchuk KH (1993) The biochemical basis of zinc physiology. Phys. Rev. 73:79-118.

Van Assche F, Clijsters H (1990) Effects of metals on enzyme activity in plants. Plant Cell Environ. 13:195-206.

Voeste D, Levine LH, Levine HG, Blüm V (2003) Pigment composition and concentrations within the plant (Ceratophyllum demersum L.) component of the STS-89 C.E.B.A.S. Mini-Module spaceflight experiment. Adv. Space Res. 31:211-214.

Waalkes M (2000) Cadmium carcinogenesis in review. J. Inorg. Biochem. 79:214-244.

Wallace A (1982) Additive, protective and synergistic effects on plants with excess trace elements. Soil Sci. 133: 319-323.

Wolff SP, Garner A, Dean R (1986) Free radicals, lipids and protein degradation. Trends Biochem. Sci. 11:27-31.

Wu FY, Wu CW (1987) Zinc in DNA replication and transcription. Annu. Rev. Nutr. 7:251.

Xiang C, Werner BL, Christensen EM, Olver DJ (2001) The biological functions of glutathione revisited in Arabidopsis transgenic plants with altered glutathione levels. Plant Physiol. 126:564-574.

Yang XE, Baligar VC, Foster JC, Martens DC (1997) Accumulation and transport of nickel in relation to organic acids in ryegrass and maize with different nickel levels. Plant Soil 196:271-276.

Zago MP, Oteiza PI (2001) The antioxidant properties of zinc: interactions with iron and antioxidants. Free Rad. Biol. Med. 31:266-274.

Zhang J, Kirkham MB (1996) Enzymatic responses of the ascorbate-glutathione cycle to drought in sorghum and sunflower plants. Plant Sci. 113:139-147.

Zhou Q, Wu Y, Xiong X (1994) Compound pollution of Cd and $\mathrm{Zn}$ and its ecological effect on rice plant. Chin. J. Appl. Ecol. 5:428-441. 